\title{
Conditions stimulating neutral detergent fiber degradation by dosing branched-chain volatile fatty acids. I: Comparison with branched-chain amino acids and forage source in ruminal batch cultures
}

\author{
Y. Roman-Garcia, ${ }^{1} \oplus$ B. L. Denton, ${ }^{2} \oplus$ K. E. Mitchell, ${ }^{2} \oplus$ C. Lee,,${ }^{2,3} \oplus$ M. T. Socha, ${ }^{4} \oplus$ and J. L. Firkins ${ }^{2 *}(\mathbb{1}$ \\ ${ }^{1}$ Cargill Animal Nutrition, Innovation Campus, Elk River, MN 55330 \\ ${ }^{2}$ Department of Animal Sciences, The Ohio State University, Columbus 43210 \\ ${ }^{3}$ Department of Animal Sciences, Ohio Agricultural Research and Development Center, The Ohio State University, Wooster 44691 \\ ${ }^{4}$ Zinpro Corporation, Eden Prairie, MN 55344
}

\begin{abstract}
Three experiments assessed branched-chain volatile fatty acid (BCVFA) stimulation of neutral detergent fiber (NDF) disappearance after $24 \mathrm{~h}$ of incubation in batch cultures derived from ruminal fluid inocula that were enriched with particulate-phase bacteria. In experiment 1, a control was compared with 3 treatments with isomolar doses of all 3 BCVFA (plus valerate), all 3 branched-chain AA (BCAA), or half of each BCVFA and BCAA mix with either alfalfa or grass hays (50\%) and ground corn grain (50\%). A portion of the BCAA and BCVFA doses were enriched with ${ }^{13} \mathrm{C}$, and valerate (also enriched with ${ }^{13} \mathrm{C}$ ) was added with BCVFA. Although BCAA yielded a similar production of BCVFA compared with dosing BCVFA, equimolar substitution of BCVFA for BCAA decreased the percentage of $\mathrm{N}$ in bacterial pellets when alfalfa hay was fed but increased $\mathrm{N}$ when grass hay was fed. Substituting BCVFA for BCAA increased total fatty acid (FA) concentration with alfalfa hay. Dosing of BCAA or BCVFA did not affect total branched-chain FA, iso-FA, or anteiso-FA percentages in bacterial total FA, whereas numerous individual $\mathrm{FA}$ isomers and their ${ }^{13} \mathrm{C}$ enrichments were affected by these treatments. Increasing recovery of the ${ }^{13} \mathrm{C}$ dose from respective labeled BCVFA primers indicated facilitated BCVFA uptake and incorporation into FA compared with BCAA, whereas increased recovery of ${ }^{13} \mathrm{C}$ from labeled $\mathrm{BCAA}$ in the bacteria pellet but not in the FA fraction suggested direct assimilation into bacterial protein. The BCVFA and valerate were dosed in varying combinations that either summed to 4 $\mathrm{m} M$ (experiment 2) or had only $1 \mathrm{~m} M$ no matter what combination (experiment 3). In general, grass hay was more responsive to stimulation in NDF digestibility by BCVFA than was alfalfa hay, which was attributed to
\end{abstract}

Received December 18, 2020.

Accepted February 18, 2021.

*Corresponding author: firkins.1@osu.edu the higher degradable protein in the latter. The net production of the BCVFA (after subtracting dose) was affected by source and combination of BCVFA. Isovalerate dosing tended to increase its own net production; in contrast, isobutyrate seemed to be used more when it was added alone, but 2-methylbutyrate seemed to be preferred over isobutyrate when 2-methylbutyrate was added. Results supported potential interactions, including potential feedback in production from feed BCAA or increased concentration-dependent competition for dosed BCVFA into cellular products. Under our conditions, the BCVFA appear to be more readily available than BCAA, probably because of regulated BCAA transport and metabolism. Valerate consistently provided no benefit. Using nonparametric ranking, all 3 BCVFA or either isovalerate or isobutyrate (both yielding iso-FA) should be combined with 2-methylbutyrate (yielding anteiso-FA) as a potential opportunity to improve NDF digestibility when rumen-degraded BCAA are limited in diets to decrease environmental impact from $\mathrm{N}$ in waste.

Key words: branched-chain volatile fatty acid, rumen bacteria, fiber degradation, batch culture

\section{INTRODUCTION}

Isovalerate, isobutyrate, and 2-methylbutyrate are branched-chain VFA (BCVFA) produced by rumen microbial deamination and decarboxylation of their respective branched-chained AA (BCAA): Leu, Val, and Ile (Stewart et al., 1997). The BCVFA and possibly valerate (derived from AA or from carbohydrate fermentation) have well known requirements for Fibrobacter succinogenes, Ruminococcus albus, and Ruminococcus flavefaciens (Andries et al., 1987), which are critical for cellulose and hemicellulose degradation in the rumen (Terry et al., 2019). Cellulolytic bacteria rely on other bacteria for provision of BCAA or BCVFA precursors (Moraïs and Mizrahi, 2019) as dynamic colonization develops with a diverse microbial consortium (Gruninger 
et al., 2019). If important precursors such as BCVFA become limited to primary colonizers, the microbial consortium might become imbalanced and lessen fiber degradability (Firkins, 2010). Along with Phe, the BCAA were incorporated directly into bacterial protein greater than most other preformed AA (Atasoglu et al., 2004). The balance of BCVFA (production minus uptake or passage) needed to optimize degradation of mixed forage-grain diets probably becomes more critical with increasing ruminal passage rates (Andries et al., 1987). Therefore, today's high-producing dairy cattle with greater DMI (and faster ruminal passage rate) would likely have a greater potential for benefit from BCVFA supplementation than when it was studied decades ago, particularly when RDP is decreased to limit $\mathrm{N}$ excretion.

Dosed ${ }^{14} \mathrm{C}$-labeled BCVFA have been recovered into their respective branched-chain fatty acid (BCFA) in bacteria grown in vitro (Allison et al., 1962; Wegner and Foster, 1963; Robinson and Allison, 1969), but the incorporation profile of BCVFA relative to BCAA as precursors for BCFA has rarely been studied. Increasing intracellular AA concentrations likely feedback-inhibit their synthesis (Hackmann and Firkins, 2015), and the coenzyme A ester of an individual BCVFA might also inhibit the de novo synthesis of its respective BCAA (Allison et al., 1984). The BCAA, especially Leu, might regulate transcription of enzymes for synthesis of multiple AA (Geiger et al., 2010; Terry et al., 2019). However, there is limited mechanistic understanding of how BCVFA are reductively carboxylated into BCAA in anaerobic bacteria.

Either BCAA or BCVFA have improved NDF disappearance, bacterial protein synthesis, or bacterial growth rate (Mir et al., 1986; Kajikawa et al., 2002; Zhang et al., 2013). Given the interchanging decarboxylation and reductive carboxylation reactions between BCAA and BCVFA (Atasoglu et al., 2004), we hypothesized that their combination would be nonadditive by allowing prioritization for synthesis of protein (from dosed BCAA) and lipid (from dosed BCVFA) without reaching inhibitory intracellular concentrations. Because fibrolytic and amylolytic bacteria have different odd- and branched-chain fatty acids (OBCFA) profiles in their membranes, increasing concentrate should decrease iso-fatty acids (FA) and increase anteiso-FA (Vlaeminck et al., 2006a). Thus, we considered different forage sources and forage:corn ratios when assessing the need for BCVFA or BCAA. Because amylolytic bacteria should grow faster and become more prevalent with increasing grain, the benefit of BCVFA over BCAA might be lessened, whereas amylolytics also might increasingly compete with cellulolytics for BCVFA under those conditions. We expected to detect increased ${ }^{13} \mathrm{C}$ recovery in BCFA when ${ }^{13} \mathrm{C}$-labeled $\mathrm{BCAA}$ was substituted with ${ }^{13} \mathrm{C}$-labeled BCVFA. We also expected increased recovery of dosed $\mathrm{NH}_{3}{ }^{-15} \mathrm{~N}$ into bacterial cells when BCAA were replaced with BCVFA.

Isovalerate and isobutyrate both yield iso-BCFA that have similar fluidity effects on the membrane, but more so than saturated FA, whereas 2-methylbutyrate yields anteiso-BCFA that increase membrane fluidity the most in anaerobic bacteria (Vlaeminck et al., 2006a). Although 2-methylbutyrate should be produced in a racemic mixture from L-Ile, anteiso-FA are produced primarily from S-enantiomers of 2-methylbutyrate (Eibler et al., 2017). Unfortunately, 2-methylbutyrate has rarely been distinguished from its co-elution with isovalerate (Roman-Garcia et al., 2016), and thus data are limited to test this hypothesis that recovery of label in anteiso-FA should be particularly nonadditive as a racemic mix of 2-methylbutyrate replaces L-Ile.

Our objectives were to compare the effect of BCAA versus BCVFA on NDF degradability and their incorporation into bacterial FA (experiment 1) and to ascertain if BCVFA combinations could be simplified (experiments 2 and 3 ) when alfalfa or grass hays were fed. In experiment 1 , we hypothesized that ${ }^{13} \mathrm{C}$-labeled BCVFA would be incorporated more into bacterial FA compared with BCAA. Of the BCVFA, we expected that isobutyrate and isovalerate would be somewhat interchangeable, but have a separate function than 2-methylbutyrate, and thus isobutyrate could replace any need for isovalerate. We hypothesized that BCVFA assimilation into bacterial BCFA would be enhanced when grass hay was fed because of its lower supply of degradable BCAA compared with alfalfa hay.

\section{MATERIALS AND METHODS}

\section{In Vitro Conditions for All Experiments}

Rumen fluid was collected from 2 cannulated Jersey cows housed according to IACUC standards at the Waterman Dairy in Columbus, Ohio. Cows were fed a standard lactation diet of about 50\% forage and $50 \%$ concentrate. Rumen fluid was strained through 2 layers of cheesecloth, combined with enough particles to enrich for particulate-associated bacteria (PAB), but not too much to prevent blending, stored in airtight containers filled to maximum to exclude air, and kept at $39^{\circ} \mathrm{C}$ in a prewarmed thermos for transportation to laboratory. Once in the laboratory, rumen fluid was blended while under $\mathrm{CO}_{2}$ for $60 \mathrm{~s}$ and strained through 8 layers of cheesecloth. Strained rumen fluid was combined with 3 parts artificial saliva buffer previously bubbled with $\mathrm{O}_{2}$-free $\mathrm{CO}_{2}$ (Goering and Van Soest, 1970) but without $\mathrm{N}$ source except as described below. After the top froth 
was aspirated, a sample of the inoculum was taken for VFA analysis. Then, $30 \mathrm{~mL}$ of this inoculum was anaerobically added (flushing with $\mathrm{O}_{2}$-free $\mathrm{CO}_{2}$ ) to $50-\mathrm{mL}$ tubes previously filled with substrate and $0.5 \mathrm{~mL}$ of the respective $\mathrm{BCVFA}$ or BCAA treatment, and the tube was capped with 1 -way valves that limited air coming in but allowed gas release. Tubes were incubated at $39^{\circ} \mathrm{C}$ in a shaking water bath. A pilot study with replicated incubation runs documented that our 1:4 dilution of ruminal fluid adequately diluted BCVFA to achieve significant differences in NDF degradability at $24 \mathrm{~h}$, whereas differences were equalized as longer incubation neared times for complete NDF degradation; hence, 24 $\mathrm{h}$ was chosen to assess various treatment differences.

After $24 \mathrm{~h}, \mathrm{pH}$ was measured, fermentation was stopped by putting tubes on ice, and $1 \mathrm{~mL}$ of $5 \mathrm{~N} \mathrm{HCl}$ was added to bring down to a pH of 2 . After being held in a refrigerator at $4^{\circ} \mathrm{C}$ for $24 \mathrm{~h}$, tubes were centrifuged at $1,000 \times g$ for $10 \mathrm{~min}$ at $4^{\circ} \mathrm{C}$ to obtain a residual fraction of substrate. Samples from the supernatant were collected, the precipitated residue was dried at $55^{\circ} \mathrm{C}$, and then it was washed with neutral detergent solution into a $600-\mathrm{mL}$ beaker to measure NDF (Van Soest et al., 1991) with the use of heat-stable amylase (ANKOM Techonologies, 2017) and sodium sulfite. Ash was not removed from NDF measurements. Degraded NDF (\%) was obtained by the following equation:

$\mathrm{NDF}$ degraded $=\frac{\text { Original substrate } \operatorname{NDF}(\mathrm{g})-\text { Residual } \mathrm{NDF}(\mathrm{g})}{\text { Original susbtrate } \operatorname{NDF}(\mathrm{g})} \times 100$.

Ammonia concentration of the supernatant was analyzed with colorimetry (Chaney and Marbach, 1962). For VFA processing, $5 \mathrm{~mL}$ from the supernatant were added to a $15-\mathrm{mL}$ plastic centrifuge tube with $1 \mathrm{~mL}$ of $25 \%$ meta-phosphoric acid, capped with a rubber stopper, and mixed with a vortex mixer. After allowing the sample to stand for $20 \mathrm{~min}, 1.9 \mathrm{~mL}$ of the mix were transferred to a $2-\mathrm{mL}$ microtube, and the rest was stored at $-20^{\circ} \mathrm{C}$ for backup. The $2-\mathrm{mL}$ centrifuge tube was centrifuged at $5,000 \times g$ for $15 \mathrm{~min}$ at $4^{\circ} \mathrm{C}$. We transferred $1.70 \mathrm{~mL}$ of the supernatant into another 2 -mL microtube and stored it at $-20^{\circ} \mathrm{C}$. Upon thawing, we added $0.17 \mathrm{~mL}$ of pivalic acid as an internal standard so that the final concentration of the internal standard was $10 \mathrm{~m} M$. The sample was centrifuged again at $5,000 \times g$ for $15 \mathrm{~min}$ at $4^{\circ} \mathrm{C}$, and the supernatant was transferred to a new tube and refrozen at $-20^{\circ} \mathrm{C}$. The last step was repeated at least twice or until there was no visible pellet. Then, $0.4 \mathrm{~mL}$ of the solution was added to a new 2 - $\mathrm{mL}$ microtube, $1 \mathrm{~mL}$ of distilled water was added, and the sample mixed with a vortex mixer. We then added $20 \mu \mathrm{L}$ of $4 N \mathrm{KOH}$ to bring the sample $\mathrm{pH}$ to between 6 and 7 because the column was sensitive to low $\mathrm{pH}$. In case the amount varied to bring $\mathrm{pH}$ to this range, the volume was always recorded, and internal standard final concentration adjusted accordingly. Finally, $1 \mathrm{~mL}$ of this solution was transferred to a GC vial, and $0.1 \mathrm{~mL}$ of $0.3 \mathrm{M}$ oxalic acid was added to obtain a final concentration of $0.03 \%$ oxalic acid. The vial was capped, mixed, and stored at $-20^{\circ} \mathrm{C}$. Upon thawing, the sample was evaluated with GLC using a Hewlett Packard 5890 glass packed column (Tightspec phase 4\% Carbowax 20M, matrix 80/120 Carbopack B DA support, $2.0 \mathrm{~m} \times 6.35 \mathrm{~mm} \times 2.0 \mathrm{~mm}$ ) that was conditioned according to manufacturer's (Supelco Inc.) instructions. The carrier gas was $\mathrm{N}_{2}$ at $24 \mathrm{~mL} / \mathrm{min}$, with $\mathrm{H}_{2}$ at $30 \mathrm{~mL} / \mathrm{min}$ and air at 300 to $400 \mathrm{~mL} / \mathrm{min}$ for the flame-ionization detector. The oven temperature was $175^{\circ} \mathrm{C}$; injection and detection temperatures were 150 and $180^{\circ} \mathrm{C}$, respectively. This column, internal standard, and temperature allowed us to separate and quantify 2-methylbutyrate and isovalerate peaks within a run time of approximately 19 min. Pivalic acid was chosen as the internal standard because it elutes between butyrate and 2-methylbutyrate and would not lengthen run time.

The VFA net production was obtained using the following formula:

$$
\begin{gathered}
\text { Net VFA production }(\mathrm{mmol} / 24 \mathrm{~h})= \\
{[24 \text {-h VFA concentration }(\mathrm{m} M)} \\
\text { - inoculum concentration }(\mathrm{m} M)-\text { dose }(\mathrm{m} M)] \\
\times \text { culture volume }(0.0305 \mathrm{~L}) .
\end{gathered}
$$

\section{Experiment 1}

Ruminal fluid was incubated in batch cultures with 3 replicate runs each with 4 tubes per treatment in a 4 $\times 2$ factorial arrangement. Treatments consisted of (1) control, (2) isovalerate, isobutyrate, 2-methylbutyrate, and valerate (BCVFA; $1 \mathrm{~m} M$ final concentration each for a total of $4 \mathrm{mM}$ ), (3) Ile, Leu, and Val (BCAA; 1 $\mathrm{m} M$ final concentration each), or (4) a 50:50 mixture of BCVFA and BCAA (Mix). A mix of all 3 BCAA optimized degradation of wheat straw NDF in vitro at $2 \mathrm{mM}$ (Zhang et al., 2013), and we reasoned that more degradable grass hay would need more BCAA. Treatments were factorialized with 2 substrates: (1) $0.25 \mathrm{~g}$ of ground corn $+0.25 \mathrm{~g}$ of alfalfa hay, or (2) $0.25 \mathrm{~g}$ of corn $+0.25 \mathrm{~g}$ of orchardgrass hay. All feeds were dried at $55^{\circ} \mathrm{C}$ and ground in a Wiley mill (Arthur H. Thomas Co.) to pass through a 2-mm screen before weighing. Measured Kjeldahl CP (Bremner and Mulvaney, 1982), NDF, ADF, and ADL were, respectively, 8.41, 13.4, 
2.98 , and $0.15 \%$ of DM for corn; $21.7,46.6,25.4$, and $6.20 \%$ of DM for alfalfa hay; and $11.9,59.5,31.2$, and $4.80 \%$ of DM for grass hay. The NDF (heat-stable amylase and sulfite), ADF, and ADL were measured sequentially (Van Soest et al., 1991).

Treatments were made isonitrogenous with $\left(\mathrm{NH}_{4}\right)_{2} \mathrm{SO}_{4}$. To study the incorporation of BCVFA and BCAA into BCFA or protein, one-fifth of the dose was replaced with ${ }^{13} \mathrm{C}$-labeled BCAA (universally labeled, 98-99 atom \%, L-configuration). One-fifth of the BCVFA doses were substituted with $\left[2,3-{ }^{13} \mathrm{C}\right.$, methyl- $\left.{ }^{13} \mathrm{C}\right]$-isobutyrate, $\left[2,3,4-{ }^{13} \mathrm{C}\right.$, methyl- $\left.{ }^{13} \mathrm{C}\right]$-isovalerate, and universally labeled valerate; [methyl- $\left.{ }^{13} \mathrm{C}\right]$-2-methylbutyrate made up the entire dose because only a single carbon was labeled and this was a racemic mix. Isotopes were purchased from Cambridge Isotope Laboratories. All BCAA and BCVFA plus valerate doses were added to 4 separate tubes per treatments. Similarly, 4 separate tubes per treatment were dosed with $1.2 \mathrm{mg}$ of $10 \%{ }^{15} \mathrm{~N}$-enriched $\left(\mathrm{NH}_{4}\right)_{2} \mathrm{SO}_{4}$.

Rumen fluid was collected from 2 cannulated Jersey cows and inoculum prepared as described previously. After $24 \mathrm{~h}$ of incubation, $\mathrm{pH}$ was measured, and fermentation was stopped by putting tubes on ice and dropping the $\mathrm{pH}(1 \mathrm{~mL}$ of $5 \mathrm{~N} \mathrm{HCl})$ to 2 , as described previously. In addition, holding the sample at $\mathrm{pH} 2$ in a refrigerator $\left(4^{\circ} \mathrm{C}\right)$ for $24 \mathrm{~h}$ facilitated PAB extraction (Whitehouse et al., 1994). Tubes were then centrifuged at $1,000 \times g$ for $10 \mathrm{~min}$ at $4^{\circ} \mathrm{C}$ to obtain a residual fraction of substrate for analysis of VFA in supernatant $\left(18,000 \times g\right.$ for $15 \mathrm{~min}$ at $\left.4^{\circ} \mathrm{C}\right)$ and NDF degradability of dried precipitate as described previously; the NDF residues on each of the 3 tubes were measured before averaging. From the supernatant, $\mathrm{NH}_{3}$ diffusion was performed before ${ }^{15} \mathrm{~N}$ analyses (Hristov et al., 2001). From 4 other replicate tubes, the pellet was resuspended with saline, combined, and washed twice before freeze drying before FA analysis following the methylation procedure of Sasser (1990). Isotope $\left({ }^{13} \mathrm{C}\right)$ enrichments of methylated bacterial FA were determined using GC (Trace 1300; Thermo Fisher Scientific) equipped with isotope-ratio MS (Delta V Advantage; Thermo Fisher Scientific). Methyl esters of FA were separated using He as a carrier (injector temperature was $240^{\circ} \mathrm{C}$ with splitless mode; initial oven temperature was $60^{\circ} \mathrm{C}$, increased $10^{\circ} \mathrm{C} / \mathrm{min}$ to $150^{\circ} \mathrm{C}, 3^{\circ} \mathrm{C} / \mathrm{min}$ to $200^{\circ} \mathrm{C}$, and then $1^{\circ} \mathrm{C} /$ min to $250^{\circ} \mathrm{C}$ ), combusted through a combustion reactor $\left(\mathrm{NiO}\right.$ and $\mathrm{CuO}$ at $\left.1,000^{\circ} \mathrm{C}\right)$, and introduced into isotope-ratio MS for ${ }^{13} \mathrm{C}$ enrichment of compounds $(\mathrm{m} / \mathrm{z}$ 44, 45, and 46). Individual FA were identified using acid methyl ester mixes (47080-U, Sigma-Aldrich; Mixture BR 2, Larodan). Isotope-ratio MS was calibrated for ${ }^{13} \mathrm{C}$ enrichment using standards of methyl FA esters with known ${ }^{13} \mathrm{C}$ enrichment (USGS71 and USGS72;
Reston Stable Isotope Laboratory). Subsamples of the bacterial pellet were analyzed using an Elemental Analyzer (Flash 2000; Thermo Fisher Scientific) equipped with isotope-ratio MS (Thermo Fisher Scientific) for ${ }^{15} \mathrm{~N}$ and ${ }^{13} \mathrm{C}$ enrichments and for the percentages of total $\mathrm{N}$ and $\mathrm{C}$. The enrichments were corrected for background to yield atom percent excess (APE). Recoveries were quantified using the following formula

$$
\begin{aligned}
& \frac{\mu \mathrm{g} \text { of }{ }^{13} \mathrm{C} \text { recovered }}{\mathrm{mg} \text { of }{ }^{13} \mathrm{C} \text { dosed }}= \\
& \frac{\mathrm{mg} \text { of } \mathrm{FA} \times \text { proportion of } \mathrm{C} \text { in } \mathrm{FA} \times \frac{\mathrm{APE}}{100}}{\mathrm{mg} \text { of }{ }^{13} \mathrm{C} \text { dosed }} \times 1,000,
\end{aligned}
$$

where the concentration of each FA and its APE were derived by GCMS, the FA (in $\mathrm{mg}$ ) was the product of recovered bacterial matter and the concentration of each FA in those bacterial pellets; the dose of ${ }^{13} \mathrm{C}$ in BCVFA treatments was as dosed, but the ${ }^{13} \mathrm{C}$ in the BCAA doses were corrected for the decarboxylated ${ }^{13} \mathrm{COOH}$.

The ${ }^{15} \mathrm{~N}$ APE in bacteria was divided by the APE of ${ }^{15} \mathrm{~N}$ in $\mathrm{NH}_{3}$ (analyzed as above and using background samples collected before dosing the isotopes) to calculate bacterial $\mathrm{N}$ derived from $\mathrm{NH}_{3}-\mathrm{N}$ (Wenner et al., 2020). Data were analyzed using PROC MIXED in SAS (version 9.4, SAS Institute Inc.) with the fixed effects of BCVFA or BCAA dose, source of substrate, and substrate by dose interaction; incubation run was a random effect. Preplanned orthogonal contrasts were control versus average of the other 3 treatments and the linear and quadratic substitution of BCAA with BCVFA in the 3 treatment doses: (1) BCAA, (2) Mix, and (3) BCVFA. When a substrate by dose interaction was significant, these contrasts were repeated by substrate. Differences were declared at $P \leq 0.05$, and trends were $P \leq 0.10$.

\section{Experiment 2}

Treatments were arranged as a $9 \times 4$ factorial with 3 replicate runs and 3 tubes per treatment per run. The 9 treatments consisted of different combinations of BCVFA: (1) control, (2) isovalerate (Ival; $4 \mathrm{mM}$ ), (3) isobutyrate (Ibut; $4 \mathrm{mM}$ ), or (4) 2-methylbutyrate (2MB; $4 \mathrm{mM})$, (5) Ibut + Ival (2 $\mathrm{m} M$ each), (6) Ival $+2 \mathrm{MB}$ (2 $\mathrm{m} M$ each), (7) Ibut + 2MB (2 mM each), (8) Ival + Ibut + 2MB (1.33 mM each), or (9) Ival + Ibut $+2 \mathrm{MB}+$ valerate $(\mathbf{V} ; 1 \mathrm{~m} M$ each $)$. The BCVFA treatments were all made to a total of $4 \mathrm{~m} M$. These 9 BCVFA treatments were factorialized with 4 substrates 
that were arranged as a $2 \times 2$ factorial: (1) $0.5 \mathrm{~g}$ of alfalfa hay, (2) $0.25 \mathrm{~g}$ of alfalfa hay $+0.25 \mathrm{~g}$ of ground corn, (3) $0.5 \mathrm{~g}$ of orchardgrass hay, or (4) $0.25 \mathrm{~g}$ of orchardgrass hay $+0.25 \mathrm{~g}$ of ground corn. All feeds were dried at $55^{\circ} \mathrm{C}$ and ground in a Wiley mill (Arthur H. Thomas Co.) to pass through a 2 -mm screen before the study.

Rumen fluid was collected from 2 cannulated Jersey cows with inoculations prepared as described previously. After $24 \mathrm{~h}$, fermentation was stopped by putting tubes on ice. The $\mathrm{pH}$ was measured and the fluid acidified to a $\mathrm{pH}$ of 2 , and $\mathrm{PAB}$ were detached as described previously. Samples for NDF degradability, VFA, and $\mathrm{NH}_{3}-\mathrm{N}$ were processed as described previously.

Data were analyzed using PROC GLM in SAS with the fixed effects of treatment, feed, and a treatment by feed interaction and the random effect of run. We had 9 treatments, resulting in 36 pairwise comparisons, which would inflate type I error. Therefore, we used the Waller-Duncan test, which accounts for both type I and type II errors using a Bayes exact test, as recommended by Carmer and Swanson (1973). This test was available in PROC GLM, but not MIXED. Using the GLM procedure yielded very similar means and standard errors to using PROC MIXED with maximum likelihood estimation. To compare means, a KRatio $=$ 100 (equivalent to $\alpha=0.05$ ) was used, and trends were evaluated with a KRatio $=50$ (equivalent to $\alpha=0.10$ ).

\section{Experiment 3}

Another batch culture experiment was performed with a $9 \times 2$ factorial arrangement of treatments with 3 replicate runs and 3 tubes per treatment in each run. Treatments consisted of different combinations of BCVFA as in experiment 2, but $1 \mathrm{~m} M$ concentrations of each BCVFA were added regardless of the number of BCVFA added; therefore, total concentration of dosed $\operatorname{acid}(\mathrm{s})$ varied among treatments. Treatments were (1) control, (2) Ival $(1 \mathrm{mM})$, (3) Ibut (1 mM), (4) 2MB (1 $\mathrm{m} M)$, (5) Ibut + Ival (1 mM each), (6) Ival + $2 \mathrm{MB}(1$ $\mathrm{m} M$ each), (7) Ibut $+2 \mathrm{MB}(1 \mathrm{~m} M$ each), (8) Ival + Ibut $+2 \mathrm{MB}(1 \mathrm{~m} M$ each $)$, or (9) Ival + Ibut $+2 \mathrm{MB}$ $+\mathrm{V}(1 \mathrm{~m} M$ each $)$. Acid treatments were factorialized with 2 substrates: (1) $0.25 \mathrm{~g}$ of alfalfa hay $+0.25 \mathrm{~g}$ of ground corn or (2) $0.25 \mathrm{~g}$ of orchardgrass hay $+0.25 \mathrm{~g}$ of ground corn. All feeds were dried at $55^{\circ} \mathrm{C}$ ground in a Wiley mill (Arthur H. Thomas Co.) to pass through a 2-mm screen before weighing.

Inoculation, collection, and analyses of samples for $\mathrm{NDF}$ degradability, VFA, and $\mathrm{NH}_{3}-\mathrm{N}$ concentration were done as described previously. Data were analyzed using PROC GLM in SAS with the random effect of run and the fixed effects of treatment, substrate, and a treatment by substrate interaction. Multiple comparisons of means were performed using the Waller-Duncan test as described in experiment 2 .

\section{RESULTS AND DISCUSSION}

\section{Experiment 1}

There was a substrate by treatment interaction $(P<$ $0.05)$ for some variables in experiment 1 . Because there were main effect differences for NDF digestibility $(P<$ $0.01)$ and most of the VFA production measurements $(P \leq 0.05)$, and differences or trends for numerous FA isomer $(P \leq 0.10)$, means for all variables are presented by substrate. Results for alfalfa + corn are presented first (top of Table 1). The contrast for the average of the 3 BCVFA and BCAA treatments tended $(P=0.06)$ to have lower $\mathrm{pH}$ compared with control, potentially indicating higher digestibility. We expected BCVFA to stimulate fibrolytic bacteria growth more rapidly in the developing adherent consortium than would BCAA, and these results might have been equalized by $24 \mathrm{~h}$ at which time treatment did not influence NDF digestibility. Wang et al. (2018) noted increased degradation rate of corn silage NDF in situ with supplementation of 2 -methylbutyrate to steers fed mixed forage and grain diets. Production (concentration $\times 30.5 \mathrm{~mL}$ of volume in each tube) of total VFA, acetate, propionate, and butyrate were not affected $(P>0.20)$ by adding BCVFA or BCAA relative to the control. There were no linear effects $(P>0.10)$ for these VFA when BCVFA replaced BCAA in only the 3 BCAA and BCVFA treatments; nor were there quadratic effects $(P>0.10)$ for propionate and butyrate. However, we identified quadratic effects $(P \leq 0.05)$ for total VFA and acetate production, primarily resulting from decreased production for Mix compared with BCAA and BCVFA. As expected from dosing the BCAA and BCVFA, productions of valerate, isovalerate, isobutyrate, and 2-methylbutyrate increased $(P<0.01)$ compared with control. Valerate increased linearly $(P<0.01)$ when BCVFA, which contained dosed valerate, was substituted for BCAA. The lack of linear and quadratic effects supports extensive deamination and decarboxylation of the dosed BCAA. Acetate:propionate tended $(P=0.09)$ to be lower for treatment differences compared with control. Ammonia-N was not affected by treatment.

When grass hay + corn was the substrate (bottom half of Table 1), pH, NDF digestibility, and production of total VFA, acetate, propionate, and butyrate were not affected $(P>0.10)$ by BCAA or BCVFA addition. Valerate, isobutyrate, isovalerate, and 2-methylbutyrate followed similar patterns as for alfalfa + corn (control vs. treatments and linearity of valerate were $P<0.01$ ), 
again documenting the BCVFA dosed and extensive catabolism of BCAA. Compared with control, $\mathrm{NH}_{3}-\mathrm{N}$ concentration at $24 \mathrm{~h}$ tended $(P=0.07)$ to increase with dosing of BCAA and BCVFA.

There was no substrate by BCVFA or BCAA treatment interaction $(P>0.20)$ for ${ }^{15} \mathrm{~N}$ enrichment from $\mathrm{NH}_{3}$, bacterial $\mathrm{C}$ percent, or total ${ }^{13} \mathrm{C}$ recovered in bacteria (Table 2). Not all of the PAB were likely detached from the particles, which would decrease recovery of dosed ${ }^{13} \mathrm{C}$. According to Whitehouse et al. (1994), whose procedure we followed, 52 to $62 \%$ of $\mathrm{PAB}$ were extracted. There was a tendency $(P=0.09)$ for a substrate by dosed treatment interaction for $\mathrm{N}$ concentration of bacteria.

When alfalfa hay + corn was the substrate (top half of Table 2), bacterial $\mathrm{N}$ did not differ $(P>0.20)$ between control and the 3 treatments with BCVFA and BCAA. Bacterial $\mathrm{N}$ concentration tended to decrease linearly $(P$ $=0.08$ ), with BCVFA substituting for BCAA, suggesting faster growth rate and protein synthesis (Bach et al., 2005). This result indicated that additional BCAA increased their incorporation into bacterial protein, as would be expected (Atasoglu et al., 2004). Dosing BCVFA or BCAA did not affect $(P>0.20$ for all contrasts $)$ bacterial ${ }^{15} \mathrm{~N}$ enrichment from ${ }^{15} \mathrm{NH}_{3}$ (i.e., bacterial $\mathrm{N}$ derived from $\mathrm{NH}_{3}-\mathrm{N}$ ). However, total ${ }^{13} \mathrm{C}$ recovered in bacteria as a percentage of dose decreased linearly $(P$ $<0.01)$ as BCVFA substituted for BCAA. A higher enrichment of ${ }^{13} \mathrm{C}$ in the total bacterial pellet for BCAA versus BCVFA was expected because BCAA assimilate directly into the larger protein fraction compared with BCVFA, labeling the priming units of OBCFA that are in low proportion of total bacterial FA. Although ${ }^{13} \mathrm{CO}_{2}$ from our decarboxylated ${ }^{13} \mathrm{C}$-BCAA doses could have minor fixation and assimilation into cellular carbon, protein synthesized from these labeled BCAA or the BCFA elongated from BCVFA should have limited, if any, ${ }^{13} \mathrm{C}$ assimilated from ${ }^{13} \mathrm{CO}_{2}$. A low ${ }^{13} \mathrm{C}$ recovery from BCAA or BCVFA doses into bacterial protein or BCFA in membranes should not be confused with a low

Table 1. Effects of dosing branched-chain AA or branched-chain VFA on 24-h pH, NDF degradability, VFA production, and ammonia concentrations in ruminal batch cultures incubated with 2 substrates (experiment 1)

\begin{tabular}{|c|c|c|c|c|c|c|c|c|}
\hline Item $^{1}$ & \multicolumn{4}{|c|}{$\operatorname{Dose}^{2}$} & SEM & \multicolumn{3}{|c|}{$P$-value ${ }^{3}$} \\
\hline \multicolumn{9}{|l|}{ Alfalfa + corn } \\
\hline NDF degradability, $\%$ & 49.5 & 52.5 & 48.3 & 50.2 & 2.6 & NS & NS & NS \\
\hline \multicolumn{9}{|l|}{ VFA production, $\mathrm{mmol} / 24 \mathrm{~h}$} \\
\hline Total VFA & 3.27 & 3.36 & 3.07 & 3.37 & 0.20 & NS & NS & 0.02 \\
\hline Butyrate & 0.558 & 0.580 & 0.424 & 0.591 & 0.068 & NS & NS & 0.12 \\
\hline Valerate & 0.0396 & 0.0442 & 0.0472 & 0.0521 & 0.0338 & $<0.01$ & 0.02 & NS \\
\hline Isobutyrate & 0.0227 & 0.0360 & 0.0362 & 0.0363 & 0.0279 & $<0.01$ & NS & NS \\
\hline Isovalerate & 0.0228 & 0.0361 & 0.0351 & 0.0374 & 0.0277 & 0.01 & NS & NS \\
\hline 2-Methylbutyrate & 0.0182 & 0.0323 & 0.0326 & 0.0337 & 0.0215 & $<0.01$ & NS & NS \\
\hline Acetate:propionate & 2.04 & 1.97 & 1.93 & 1.93 & 0.05 & 0.09 & NS & NS \\
\hline $\mathrm{NH}_{3}-\mathrm{N}, \mathrm{mg} / \mathrm{dL}$ & 20.5 & 21.0 & 20.4 & 21.1 & 4.3 & NS & NS & NS \\
\hline \multicolumn{9}{|l|}{ VFA Production, $\mathrm{mmol} / 24 \mathrm{~h}$} \\
\hline Acetate & 1.55 & 1.60 & 1.60 & 1.59 & 0.15 & NS & NS & NS \\
\hline Propionate & 0.711 & 0.747 & 0.753 & 0.755 & 0.071 & 0.13 & NS & NS \\
\hline Butyrate & 0.518 & 0.520 & 0.519 & 0.531 & 0.048 & NS & NS & NS \\
\hline Valerate & 0.0285 & 0.0331 & 0.0364 & 0.0332 & 0.0264 & $<0.01$ & $<0.01$ & NS \\
\hline Isobutyrate & 0.0168 & 0.0314 & 0.0314 & 0.0307 & 0.0245 & $<0.01$ & NS & NS \\
\hline Isovalerate & 0.0156 & 0.0316 & 0.0309 & 0.0310 & 0.0236 & $<0.01$ & NS & NS \\
\hline 2-Methylbutyrate & 0.0134 & 0.0288 & 0.0280 & 0.0289 & 0.0189 & $<0.01$ & NS & NS \\
\hline Acetate:propionate & 2.18 & 2.14 & 2.12 & 2.11 & 0.04 & NS & NS & NS \\
\hline $\mathrm{NH}_{3}-\mathrm{N}, \mathrm{mg} / \mathrm{dL}$ & 18.3 & 20.4 & 19.4 & 20.1 & 4.5 & 0.07 & NS & NS \\
\hline
\end{tabular}

${ }^{1}$ Substrate was either $0.25 \mathrm{~g}$ of alfalfa hay $+0.25 \mathrm{~g}$ of ground corn or $0.25 \mathrm{~g}$ of grass hay $+0.25 \mathrm{~g}$ of ground corn. Substrate by dose interaction was $P>0.15$ for any of the variables presented in this table.

${ }^{2}$ Control $=$ no dose; $\mathrm{BCAA}=$ branched-chain AA, $1 \mathrm{~m} M$ Leu $+1 \mathrm{~m} M$ Val $+1 \mathrm{~m} M$ Ile; BCVFA $=$ branched-chain VFA, $1 \mathrm{~m} M$ isovalerate +1 $\mathrm{m} M$ isobutyrate $+1 \mathrm{~m} M 2$-methylbutyrate $+1 \mathrm{~m} M$ valerate; Mix $=50: 50$ mix of BCVFA and BCAA.

${ }^{3} \mathrm{CON}$ vs. TRT $=$ contrast between control and average of all other means; for BCAA, Mix, and BCVFA only, L $=$ linear and Q $=$ quadratic contrast of substituting BCVFA for BCAA. NS $=P>0.20$. 
Table 2. Effects of dosing branched-chain AA or branched-chain VFA on bacterial composition and enrichment from ruminal batch cultures incubated with 2 substrates (experiment 1)

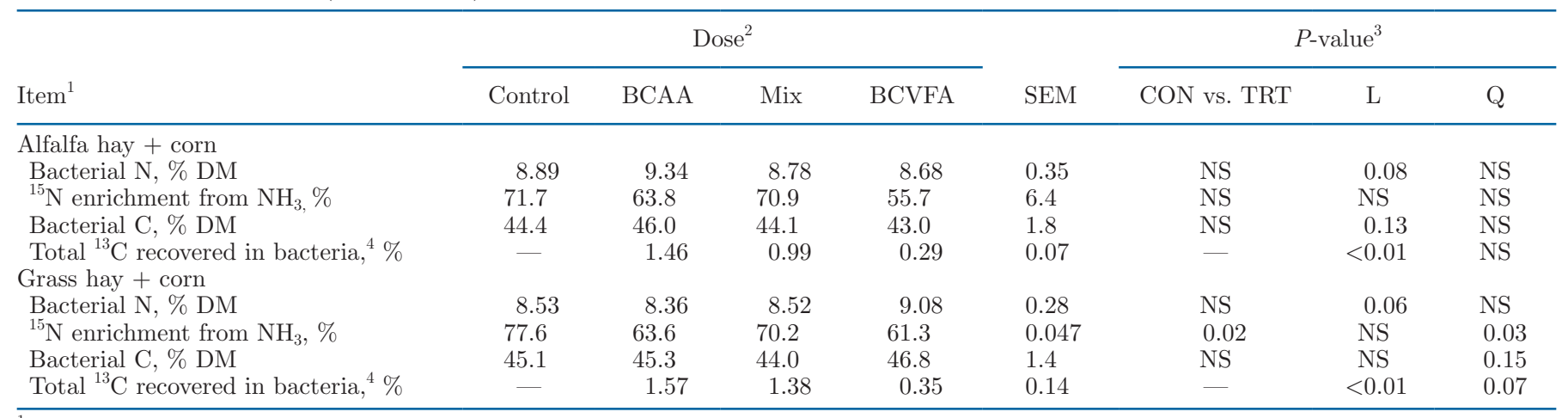

${ }^{1}$ Substrate was either $0.25 \mathrm{~g}$ of alfalfa hay $+0.25 \mathrm{~g}$ of ground corn or $0.25 \mathrm{~g}$ of grass hay $+0.25 \mathrm{~g}$ of ground corn. There was a tendency $(P=$ 0.09 ) for a substrate by dose interaction on bacterial N\%. Substrate by dose interaction was $P>0.35$ for the rest of the variables presented in this table.

${ }^{2}$ Control $=$ no dose; BCAA $=$ branched-chain AA, $1 \mathrm{~m} M$ Leu $+1 \mathrm{~m} M$ Val $+1 \mathrm{~m} M$ Ile; BCVFA $=$ branched-chain VFA, $1 \mathrm{~m} M$ isovalerate +1 $\mathrm{m} M$ isobutyrate $+1 \mathrm{~m} M 2$-methylbutyrate $+1 \mathrm{~m} M$ valerate; Mix $=50: 50$ mix of BCVFA and BCAA.

${ }^{3} \mathrm{CON}$ vs. TRT $=$ contrast between control and average of all other means; for BCAA, Mix, and BCVFA only, $\mathrm{L}=$ linear and $\mathrm{Q}=\mathrm{quadratic}$ contrast of substituting BCVFA for BCAA. NS $=P>0.20$.

${ }^{4}$ Moles of ${ }^{13} \mathrm{C}$ recovered in total bacterial pellet expressed as a percentage of total ${ }^{13} \mathrm{C}$ from total BCAA or BCVFA dosed. Control was not dosed with ${ }^{13} \mathrm{C}$ label.

importance, though, because (1) the molar dose of ${ }^{13} \mathrm{C}$ in the tracer is low compared with the amount (moles) of carbon in unlabeled tracee of BCVFA or BCAA in the inoculum and those continuously produced over time and (2) much of the carbon from nonbranched FA or AA theoretically is not enrichable (i.e., not produced from BCVFA or BCAA precursors).

When grass hay + corn was the substrate, bacterial $\mathrm{N}$ percentage did not differ $(P>0.20)$ between control and dosing BCVFA or BCAA (bottom half of Table 2). However, bacterial $\mathrm{N}$ tended to increase linearly $(P=$ 0.06) when BCVFA was substituted for BCAA, which was opposite to the linear decrease observed with alfalfa hay. Dosing BCVFA or BCAA decreased $(P=0.02){ }^{15} \mathrm{~N}$ enrichment from $\mathrm{NH}_{3}$ compared with control. The quadratic response $(P=0.03)$ for percentage of $\mathrm{N}$ derived from $\mathrm{NH}_{3}-\mathrm{N}$ for grass hay was a result of the greater value for Mix. These were the opposite of expectations; dosing of BCAA was expected to increase assimilation of those precursors into protein, thus decreasing the assimilation of $\mathrm{NH}_{3^{-}}{ }^{15} \mathrm{~N}$ into BCAA synthesized de novo. All BCAA are produced from pyruvate, small amounts of Ile can be derived from other sources, and each BCAA can be derived from reductive carboxylation of its respective BCVFA followed by branchedchain aminotransferase to assimilate N (Atasoglu et al., 2004). Bacterial protein is high in BCAA (Sok et al., 2017). A possible explanation for results being different from expectations is that providing BCAA stimulated protein synthesis (not measured in our study), which in turn increased the assimilation of $\mathrm{NH}_{3}$ to synthesize other AA in addition to BCAA. Dosing BCVFA has increased bacterial protein synthesis in vitro with high fiber substrates (Russell and Sniffen, 1984; Gorosito et al., 1985). Also, Gorosito et al. (1985) and Misra and Thakur (2012) noted lower $\mathrm{NH}_{3}-\mathrm{N}$ concentration with BCVFA supplementation in batch culture, suggesting greater protein synthesis. Total ${ }^{13} \mathrm{C}$ recovered in bacteria as a percentage of ${ }^{13} \mathrm{C}$ dosed decreased linearly $(P<$ 0.01) with BCVFA substituted for BCAA regardless of forage substrate, with a tendency for a quadratic tendency $(P=0.07)$ such that Mix was similar to BCAA with grass hay.

When alfalfa + corn was the substrate, total FA in bacterial DM quantitatively recovered per incubation tube at $24 \mathrm{~h}$ was not affected $(P>0.15)$ by BCVFA or BCAA treatment, but the average of BCVFA and BCAA treatments increased $(P=0.03)$ the percentage of FA in bacteria compared with control (Table 3 ). Only $13: 0$ and anteiso-14:0 tended $(P=0.08)$ to be higher in bacterial total FA from those 3 treatments compared with control. There was a quadratic effect $(P$ $=0.04)$ on anteiso- $15: 0$ and trends $(P<0.07)$ for 11:0, 13:0, and total OCFA such that the BCAA treatment had the highest percentage of these FA compared with Mix and BCVFA. In contrast with our hypothesis, dosing BCVFA or BCAA did not affect $(P>0.20)$ total BCFA percentage of total FA.

When grass hay + corn was the substrate, dosing BCVFA or BCAA did not affect total bacterial FA recovered per tube or the FA percentage in those recovered bacteria $(P>0.15$; Table 4$)$. The combination 
Table 3. Effects of dosing branched-chain AA or branched-chain VFA on bacterial fatty acid (FA) composition in ruminal batch cultures when substrate was alfalfa + corn $(\text { experiment } 1)^{1}$

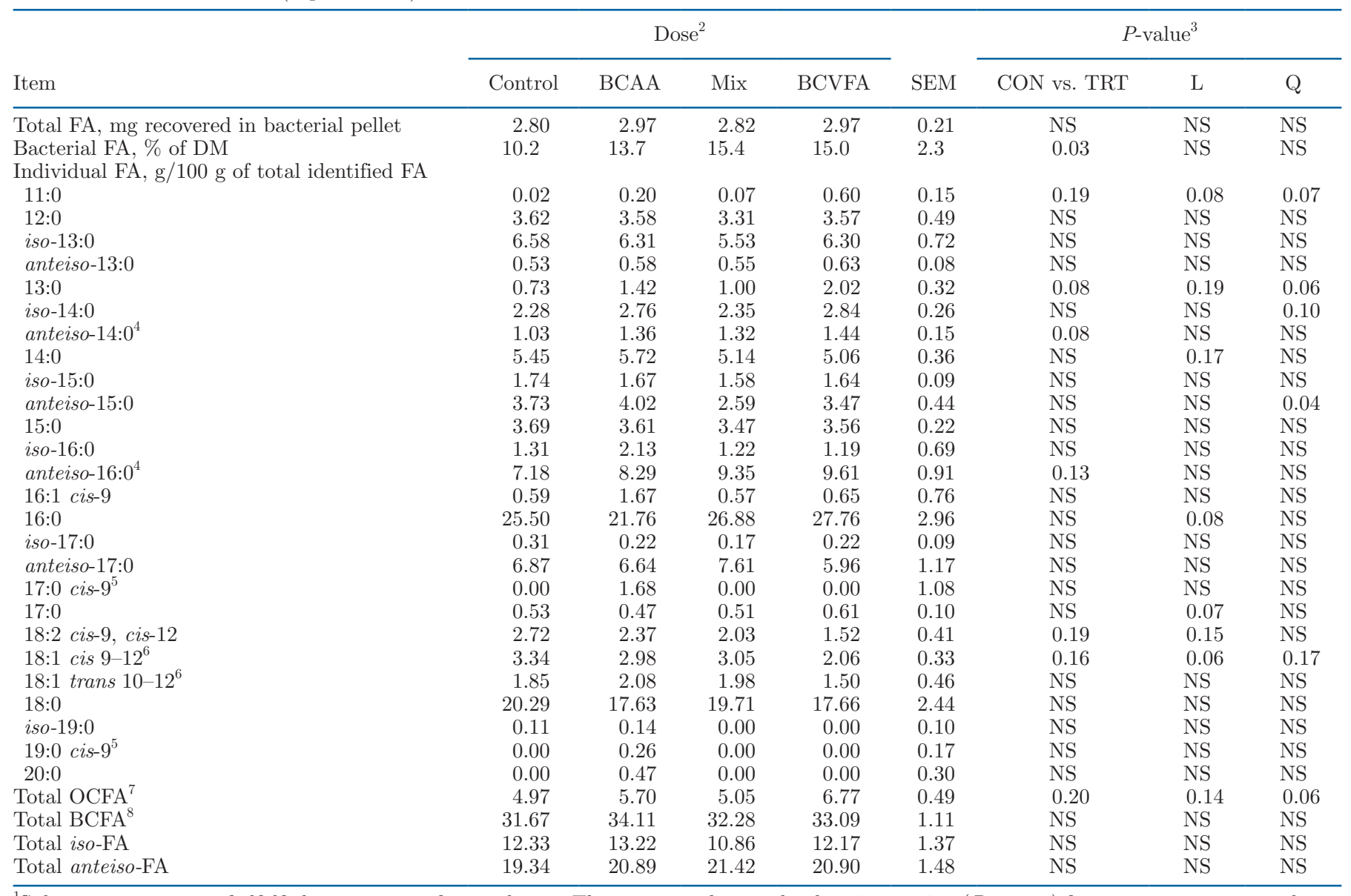

${ }^{1}$ Substrate was $0.25 \mathrm{~g}$ of alfalfa hay $+0.25 \mathrm{~g}$ of ground corn. There was a substrate by dose interaction $(P<0.05)$ for $11: 0$, anteiso-15:0 and 18:2 cis-9, cis-12. There were tendencies $(P<0.10)$ for a substrate by dose interaction for 13:0, iso-15:0, anteiso-16:0, and 16:0. Substrate by dose interaction was $P>0.15$ for the rest of the variables.

${ }^{2}$ Control $=$ no dose BCAA $=$ branched-chain AA, $1 \mathrm{~m} M$ Leu $+1 \mathrm{~m} M$ Val $+1 \mathrm{~m} M$ Ile; BCVFA $=$ branched-chain VFA, $1 \mathrm{~m} M$ isovalerate +1 $\mathrm{m} M$ isobutyrate $+1 \mathrm{~m} M$ 2-methylbutyrate $+1 \mathrm{~m} M$ valerate; Mix $=50: 50$ mix of BCVFA and BCAA.

${ }^{3} \mathrm{CON}$ vs. TRT $=$ contrast between control and all other means; for BCAA, Mix, and BCVFA only, $\mathrm{L}=$ linear and $\mathrm{Q}=$ quadratic contrast for BCVFA substituting for BCAA. NS $=P>0.20$

${ }^{4}$ Anteiso-FA are expected to be odd chain, so these are likely fatty aldehydes.

${ }^{5} 17: 0$ cis-9 = 17:0 cis-9, 10-methylenehexadecanoate; 19:0 cis-9 = 19:0 cis-9, 10-methylenehexadecanoate.

${ }^{6}$ Isomers in this range are summed because they could not be distinguished.

${ }^{7}$ Sum of all odd straight-chain FA.

${ }^{8}$ Sum of all branched-chain FA that include iso-FA and anteiso-FA.

of the $3 \mathrm{BCAA}$ and BCVFA treatments increased $(P$ $<0.02)$ iso-15:0, 15:0, and iso-17:0 concentrations compared with control. Substituting BCVFA for BCAA tended $(P=0.07)$ to linearly increase 17:0 percentage of total FA. When we dosed BCVFA but not BCAA, we included valerate, which elongates to straight-chain OCFA. Concentration of 18:2 cis-9,cis-12 increased at a decreasing rate (linear $P=0.02$ and quadratic $P=$ 0.02 ) with BCVFA substituting for BCAA. The percentage of anteiso-13:0, 18:1 cis 9-12, and 18:1 trans 10-12 (isomers in this range are summed because they could not be distinguished) had a quadratic response $(P \leq 0.03)$ such that Mix had higher percentages in the total FA than did the BCAA or BCVFA treatments. The increase in 18:1 isomers in bacterial total FA suggested the incorporation of biohydrogenation intermediates that are more fluidizing than saturated FA (Moon and Anderson, 2001). In that report, Eubacterium cellulosolvens increased its membrane fluidity when it was shifted from cellobiose to cellulose as substrate, presumably to support extracellular cellulase complexes. 
Table 4. Effects of dosing branched-chain AA or branched-chain VFA on bacterial fatty acid (FA) composition in ruminal batch cultures when substrate was orchardgrass hay + corn $(\text { experiment } 1)^{1}$

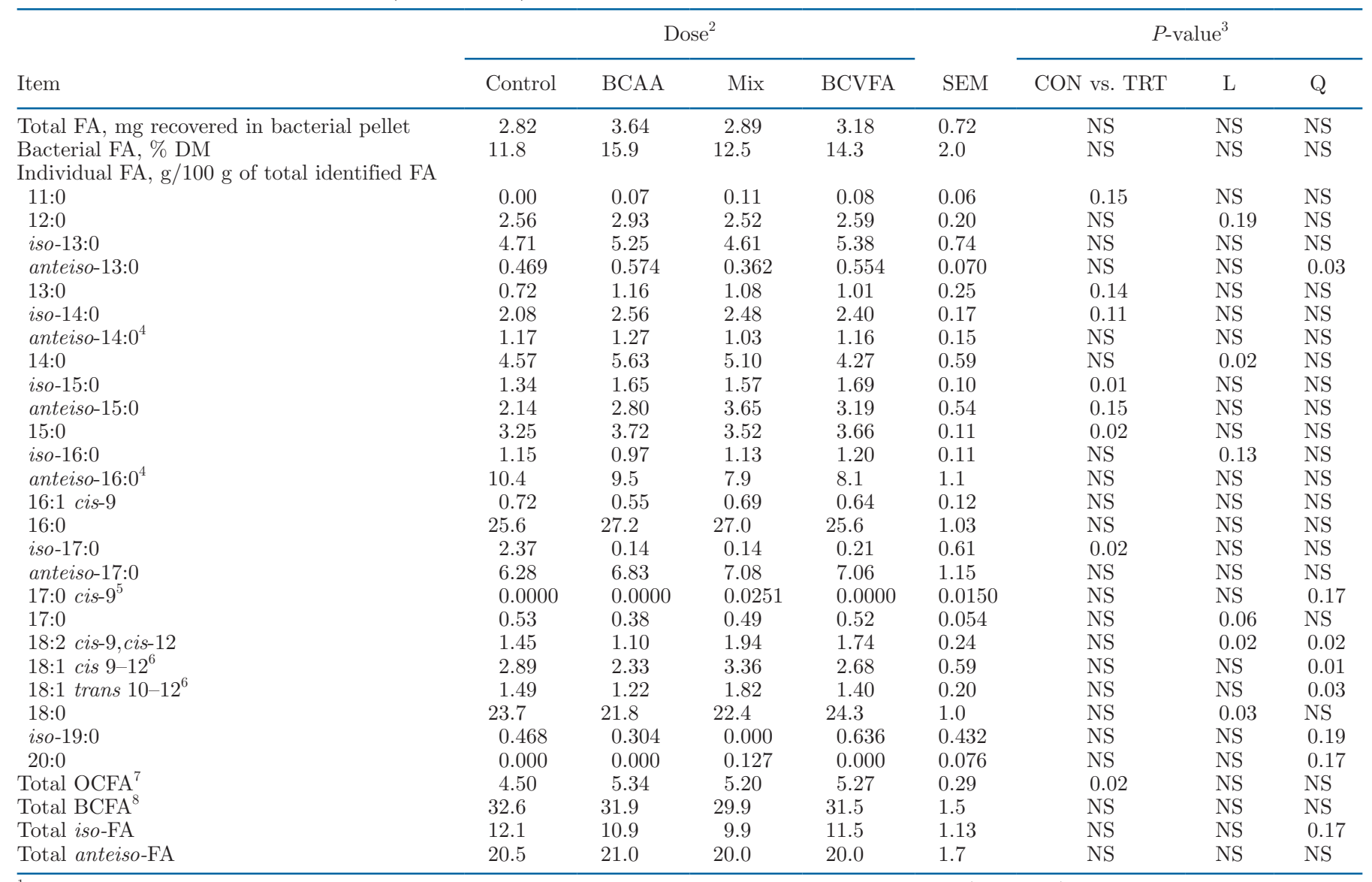

${ }^{1}$ Substrate was $0.25 \mathrm{~g}$ of orchardgrass hay $+0.25 \mathrm{~g}$ of ground corn. There was a substrate by dose $(P<0.05)$ for 11:0, anteiso-15:0 and 18:2 cis-9, cis-12. There was a tendency $(P<0.10)$ for a substrate by dose interaction for 13:0, iso-15:0, anteiso-16:0, and 16:0. substrate by dose interaction was $P>0.15$ for the rest of the variables presented in this table.

${ }^{2}$ Control $=$ no dose BCAA $=$ branched-chain AA, $1 \mathrm{~m} M$ Leu $+1 \mathrm{~m} M$ Val $+1 \mathrm{~m} M$ Ile; BCVFA $=$ branched-chain VFA, $1 \mathrm{~m} M$ isovalerate +1 $\mathrm{m} M$ isobutyrate $+1 \mathrm{~m} M 2$-methylbutyrate $+1 \mathrm{~m} M$ valerate; Mix $=50: 50$ mix of BCVFA and BCAA.

${ }^{3} \mathrm{CON}$ vs. TRT $=$ contrast between control and average of all other means; For BCAA, Mix, and BCVFA only, $\mathrm{L}=$ linear and $\mathrm{Q}=$ quadratic contrast for BCVFA substituting for BCAA. NS $=P>0.20$.

${ }^{4}$ Anteiso-FA are expected to be odd chain, so these are likely fatty aldehydes.

${ }^{5} 17: 0$ cis- $9=17: 0$ cis-9, 10-methylenehexadecanoate.

${ }^{6}$ Isomers in this range are summed because they could not be distinguished.

${ }^{7}$ Sum of all odd straight-chain FA.

${ }^{8} \mathrm{Sum}$ of all branched-chain FA that include iso-FA and anteiso-FA.

The bacterial pellet from the Mix treatment was the only one in which 20:0 FA was detected. Because increasing chain length increases rigidity, 20:0 might have countered the incorporation of 18:1 to balance membrane fluidity. The consistency of anteiso-FA among all treatments probably reflected the requirement by many bacteria for 2-methylbutyrate. Contrary to our study, Eibler et al. (2017) noted increased anteiso-FA formation when dosing isoleucine (the precursor for 2-methylbutyrate).

Dosing BCVFA or BCAA did not affect $(P>0.15)$ total ${ }^{13} \mathrm{C}$ recovered in $\mathrm{FA}$ in the entire bacterial pel- let per tube when derived as a percentage of total ${ }^{13} \mathrm{C}$ dosed when alfalfa hay + corn was the substrate (Table $5)$. Of the ${ }^{13} \mathrm{C}$ recovered in bacteria, the percentage that was incorporated in FA increased linearly $(P=$ $0.02)$ as BCVFA substituted for BCAA. These results can be explained by linear increases $(P \leq 0.05)$ in ${ }^{13} \mathrm{C}$ recovered from anteiso-14:0, iso-16:0, and 17:0, and linear tendencies $(P \leq 0.08)$ for recoveries from 13:0 and iso-17:0. Quadratic responses $(P \leq 0.07)$ were noted for 11:0, 16:1 cis-9, and anteiso-17:0 because the Mix treatment had the highest recovery of dosed label. Anteiso-14:0 or anteiso-16:0 are very likely misidenti- 
Table 5. Effects of dosing branched-chain AA or branched-chain VFA on bacterial fatty acid (FA) ${ }^{13} \mathrm{C}$ enrichment in ruminal batch cultures when substrate was alfalfa hay + corn (experiment 1$)^{1}$

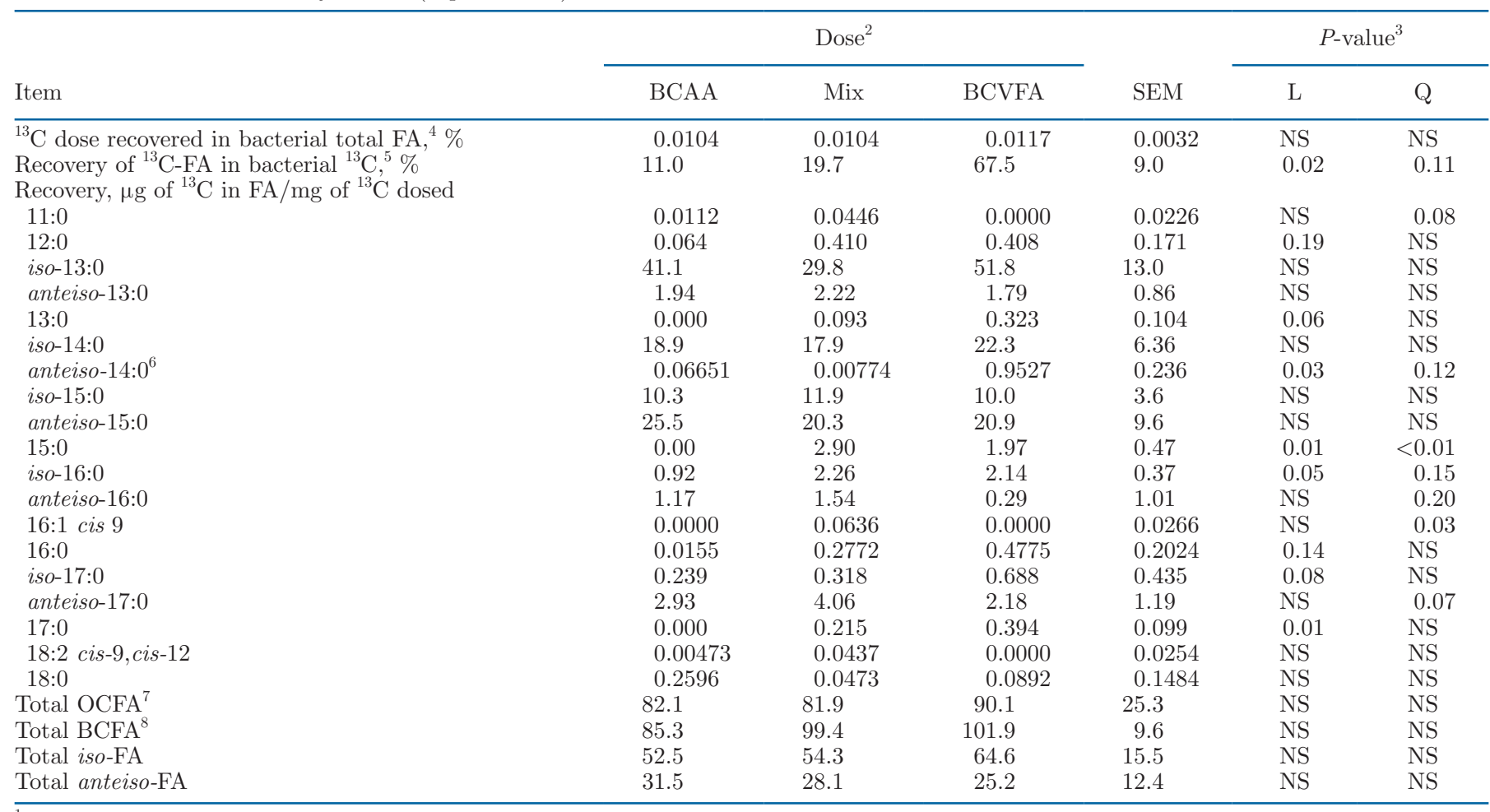

${ }^{1}$ Substrate was $0.25 \mathrm{~g}$ of alfalfa hay $+0.25 \mathrm{~g}$ of ground corn. There was a substrate by dose interaction $(P<0.05)$ for anteiso-14:0, 15:0, anteiso-17:0, 18:0, and total OCFA. Substrate by dose was $P>0.15$ for the rest of the variables presented in this table.

${ }^{2}$ Control $=$ no dose BCAA $=1 \mathrm{~m} M$ Leu $+1 \mathrm{~m} M$ Val $+1 \mathrm{~m} M$ Ile; BCVFA $=1 \mathrm{~m} M$ isovalerate $+1 \mathrm{~m} M$ isobutyrate $+1 \mathrm{~m} M 2$-methylbutyrate $+1 \mathrm{~m} M$ valerate; $\mathrm{Mix}=50: 50 \mathrm{mix}$ of $\mathrm{BCVFA}$ and BCAA.

${ }^{3} \mathrm{~L}=$ linear and $\mathrm{Q}=$ quadratic contrast as BCVFA substituted for BCAA. NS $=P>0.20$.

${ }^{4}$ Expressed as percent of ${ }^{13} \mathrm{C}$ dosed.

${ }^{5}$ Calculated as ${ }^{13} \mathrm{C}$ recovered in $\mathrm{FA}(\mathrm{mg}) /$ total ${ }^{13} \mathrm{C}$ recovered in the bacteria pellet $(\mathrm{mg}) \times 100$.

${ }^{6}$ Anteiso-FA are expected to be odd chain, so these are likely fatty aldehydes.

${ }^{7}$ Sum of all odd straight-chain FA.

${ }^{8}$ Sum of all branched-chain FA that include iso-FA and anteiso-FA.

fied in our approach. Elongation of primers occurs by adding 2 carbons each cycle (Parsons and Rock, 2013), and anteiso-FA are formed primarily as odd-chain FA elongated from 2-methylbutryrate (or its precursor, isoleucine). Alpha oxidation (removal of 1 carbon) would yield these even-chain anteiso-FA, but this pathway is very unlikely in ruminal microbes $(\mathrm{Wu}$ and Palmquist, 1991). The bacterial standards probably elute at a similar retention time as odd-chain fatty aldehydes of chain length 1 carbon lower (i.e., the standard anteiso-14:0 is probably either a 14:0 or branched 13:0 dimethyl aldehyde), according to the chromatogram presented by Alves et al. (2013). Although this supposition needs corroboration, aldehydes are widely recovered in the plasmalogen fraction of anaerobic (including rumen) bacteria, probably packing more densely than the fatty acyl components of the phospholipid membrane (Goldfine, 2017). Increasing the substitution of BCVFA for
BCAA increased enrichments of 13:0, 15:0, and 17:0 linearly $(P<0.01)$. Total iso- and anteiso-FA were not affected by treatment, suggesting these FA are regulated by unknown mechanisms to maintain a consistent profile needed for membrane fluidity. The BCVFA dose was expected to increase ${ }^{13} \mathrm{C}$ enrichment of OCFA compared with BCAA because the dosed ${ }^{13} \mathrm{C}$-enriched valerate should compete with even-chain primers for elongation (Vlaeminck et al., 2006a).

When grass hay + corn was the substrate, ${ }^{13} \mathrm{C}$ recovered in bacterial FA from all bacterial matter harvested in incubation tubes was not affected $(P \geq 0.12)$ by treatment (Table 6). Of all of the recovered ${ }^{13} \mathrm{C}$ from bacterial pellets, increasing BCVFA substitution for BCAA had linear $(P<0.01)$ and quadratic $(P=0.01)$ responses for that ${ }^{13} \mathrm{C}$ recovered in FA such that Mix was similar to BCAA. The BCVFA primers apparently were incorporated into FA at a faster rate and 
extent than were those from decarboxylated BCAA. Substituting BCVFA for BCAA linearly increased $(P \leq$ 0.03 ) enrichments of 13:0, 15:0, iso-16:0, anteiso-17:0, and 17:0, and tended $(P=0.06)$ to increase iso-15:0 when grass hay + corn was used as substrate (Table 6). There was only one quadratic response for an individual FA, which was the unknown peak eluting at the same time as the anteiso-14:0 standard, and its proportion was lower for BCVFA than Mix. Only when BCVFA were dosed alone was there enrichment detected in 18:0 (linear was $P=0.01$, quadratic was $P=0.07$ ). As expected based on dosage of labeled valerate, total OCFA enrichment increased linearly $(P=0.01)$ as BCVFA increasingly substituted for BCAA.
For BCAA to be incorporated into FA, they need to be deaminated (or transaminated) and decarboxylated (Kaneda, 1991), probably by amylolytic bacteria in the rumen, which could take longer and lessen their rate of incorporation into bacterial FA compared with BCVFA directly dosed. Increased intracellular BCAA regulates numerous pathways in bacteria, including operons for AA synthesis and BCAA transporters (Kaiser and Heinrichs, 2018); little is known about ruminal bacteria, although we assume that they have similar regulation. Although FA synthesis is integrated with general growth responses, relatively little is known about its regulation except that long chain fatty acylACP (acyl carrier protein) feedback inhibits acetyl

Table 6. Effects of dosing branched-chain AA or branched-chain VFA on bacterial fatty acid (FA) ${ }^{13} \mathrm{C}$ enrichment on ruminal batch cultures when substrate was orchardgrass hay + corn (experiment 1$)^{1}$

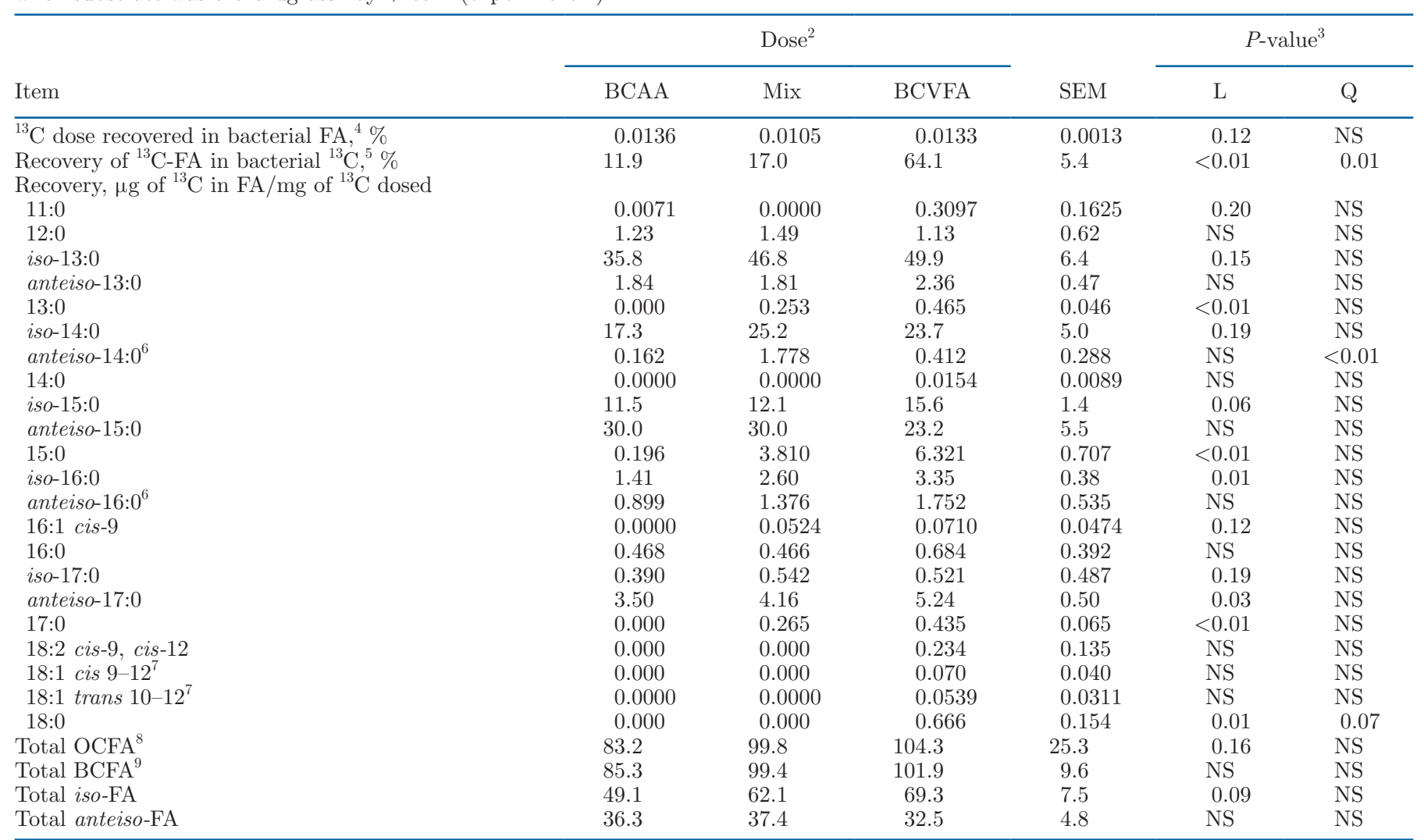

${ }^{1}$ Substrate was $0.25 \mathrm{~g}$ of alfalfa hay $+0.25 \mathrm{~g}$ of ground corn. There was a substrate by dose interaction $(P<0.05)$ for anteiso-14:0, 15:0, anteiso-17:0, 18:0, and total OCFA. Substrate by dose was $P>0.15$ for the rest of the variables presented in this table.

${ }^{2} \mathrm{BCAA}=$ branched-chain AA, $1 \mathrm{~m} M$ Leu $+1 \mathrm{~m} M$ Val $+1 \mathrm{~m} M$ Ile; BCVFA = branched-chain VFA, $1 \mathrm{~m} M$ isovalerate $+1 \mathrm{~m} M$ isobutyrate + $1 \mathrm{~m} M$ 2-methylbutyrate $+1 \mathrm{~m} M$ valerate; Mix $=50: 50 \mathrm{mix}$ of BCVFA and BCAA.

${ }^{3} \mathrm{~L}=$ linear and $\mathrm{Q}=$ quadratic contrast of BCVFA substituting for BCAA. NS $=P>0.20$.

${ }^{4}$ Expressed as percent of ${ }^{13} \mathrm{C}$ dosed.

${ }^{5}$ Calculated as ${ }^{13} \mathrm{C}$ recovered in $\mathrm{FA}(\mathrm{mg}) /$ total ${ }^{13} \mathrm{C}$ recovered in the bacteria pellet $(\mathrm{mg}) \times 100$.

${ }^{6}$ Anteiso-FA are expected to be odd chain, so these are likely fatty aldehydes.

${ }^{7}$ Isomers in this range are summed because they could not be distinguished.

${ }^{8}$ Sum of all odd straight-chain FA.

${ }^{9} \mathrm{Sum}$ of all branched-chain FA that include iso-FA and anteiso-FA. 
CoA carboxylase in those bacteria evaluated and also that perturbations of the membrane integrity can arrest cellular growth (Parsons and Rock, 2013).

Dosed BCVFA probably compete with other primers based on their relative concentrations (Vlaeminck et al., 2006a), whereas varying patterns of FA or fatty aldehydes are associated with different strains of ruminal bacteria (Minato et al., 1988, Vlaeminck et al., 2006b). The initiating condensing enzyme for long-chain fatty acid formation, FabH, prefers branched-chain primers in the gram-positive nonruminal bacteria Bacillus subtilis and Staphylococcus aureus, but the elongation module catalyzed by the FabG enzyme is shared by branched- and straight-chain components (Parsons and Rock, 2013). When grass hay was the substrate, BCVFA supplementation increased OBCFA compared with when alfalfa hay was the substrate. Grass hay has more hemicellulose, which is widely used by predominant gram-positive bacteria such as Butyrivibrio and Ruminococcus. However, FabH was annotated only in two-thirds of the butyrivibrio genomes (Hackmann and Firkins, 2015).

In studies dosing individual labeled BCVFA, the majority of the label was recovered in the protein fraction of pure cultures of amylolytic bacteria (Allison and Peel, 1971). For mixed rumen bacteria, the majority of the label from ${ }^{14} \mathrm{C}$-labeled isovalerate and ${ }^{14} \mathrm{C}$-labeled isobutyrate was recovered in protein. However, Wegner and Foster (1963) recovered most of the isobutyrate in the lipid fraction of $F$. succinogenes S85. Although $F$. succinogenes $\mathrm{S} 85$ has the genes for BCAA transport (Suen et al., 2011), it still requires valerate or another straight-chain VFA plus either isobutyrate or 2-methylbutyrate (Dehority et al., 1967). Robinson and Allison (1969) noted incorporation $\left[1-{ }^{14} \mathrm{C}\right]-2$-methylbutyrate into the lipid and protein fractions from most rumen strains of amylolytic and fibrolytic bacteria that they tested. Although they are from the same genus and have a similar cellulolytic niche, incorporation into lipids ranged from only $5 \%$ for $R$. flavefaciens C-94 to $88 \%$ for $R$. albus 7 . Thus, incorporation of BCVFA presumably depends on intracellular concentrations of intermediates and relative growth rates. In the rumen, BCVFA incorporation into the BCFA fraction was thought to be more in fibrolytics than nonfibrolytics (Vlaeminck et al., 2006b).

Based on extrapolation from nonruminal bacteria, the catabolism of BCAA is likely regulated in ruminal bacteria. The BCAA are first converted into their respective keto acid and then to their acyl-coA by the branched-chain $\alpha$ keto acid dehydrogenase complex in Bacillus (Kaneda, 1977). Expression of the bkd gene cluster, which is responsible for this dehydrogenase activity, is promoted by the branched-chain keto acid and not by the BCAA in Enterococcus faecalis (Ward et al., 2000), and thus the conversion of BCAA to their keto acid could delay the BCFA incorporation process when BCAA are dosed versus BCVFA. In mixed ruminal bacteria, BCAA deamination was limited by reducing equivalent disposal (Hino and Russell, 1985).

\section{Experiment 2}

There was no substrate $\times$ BCVFA treatment interaction $(P>0.15)$ for $\mathrm{pH}$, NDF degradability, VFA pool size, and $\mathrm{NH}_{3}-\mathrm{N}$ concentration. Main effects of substrate are reported in Supplemental Table S1 (https: //doi.org/10.3168/jds.2020-20054). The $\mathrm{pH}$ did not differ for the main effect of BCVFA treatment (Table $7)$. Dosing Ival, Ibut, Ival $+2 \mathrm{MB}$, Ibut $+2 \mathrm{MB}$, or all the BCVFA with or without valerate increased $(P \leq$ $0.05)$ NDF degradability compared with control. There was no difference $(P>0.10)$ in NDF degradability between any of the combinations of BCVFA. Dosing $2 \mathrm{MB}$ alone or Ibut + Ival increased NDF degradability numerically. Yang et al. (2002) noted improved NDF degradability of alfalfa hay, grass hay, and grass silage when isobutyrate or isovalerate were dosed individually or when leucine-valine dipeptides were dosed, but they did not test 2-methylbutyrate.

To avoid confusion, hereafter all VFA actually measured will be spelled out, whereas the VFA that were dosed will be consistent with their treatment identifications. Only the $2 \mathrm{MB}$ and the Ibut + Ival treatments did not increase NDF degradability. Dosing 2MB alone did not improve fiber degradability as much as the other treatments, perhaps because 2-methylbutyrate (yielding anteiso-FA) needs to be in a proper ratio with isobutyrate or isovalerate (yielding iso-FA).

Net production (i.e., subtracting the dose) of total VFA was not affected by BCVFA treatment $(P>$ $0.10)$, but control or dosing $2 \mathrm{MB}$ alone tended $(P<$ $0.10)$ to decrease total VFA net production compared with dosing Ibut + Ival or Ibut $+2 \mathrm{MB}$ (Table 7 ). Both control and 2MB had lower NDF degradability, which explains the lower production of VFA. However, dosing Ibut + Ival increased net production of total VFA despite the numerically lower NDF degradability. Abundant noncellulolytic bacteria in the rumen, such as Megasphaera elsdenii and Prevotella ruminicola, produce BCVFA from trypticase and do not require BCVFA in the medium to grow (Allison, 1978; Allison et al., 1984). In contrast, $R$. flavefaciens, $R$. albus, and $F$. succinogenes require isobutyrate more than 2-methylbutyrate; they apparently do not specifically require isovalerate, which could stimulate growth but can be substituted by either isobutyrate or 2-methylbutyrate (Dehority et al., 1967). 


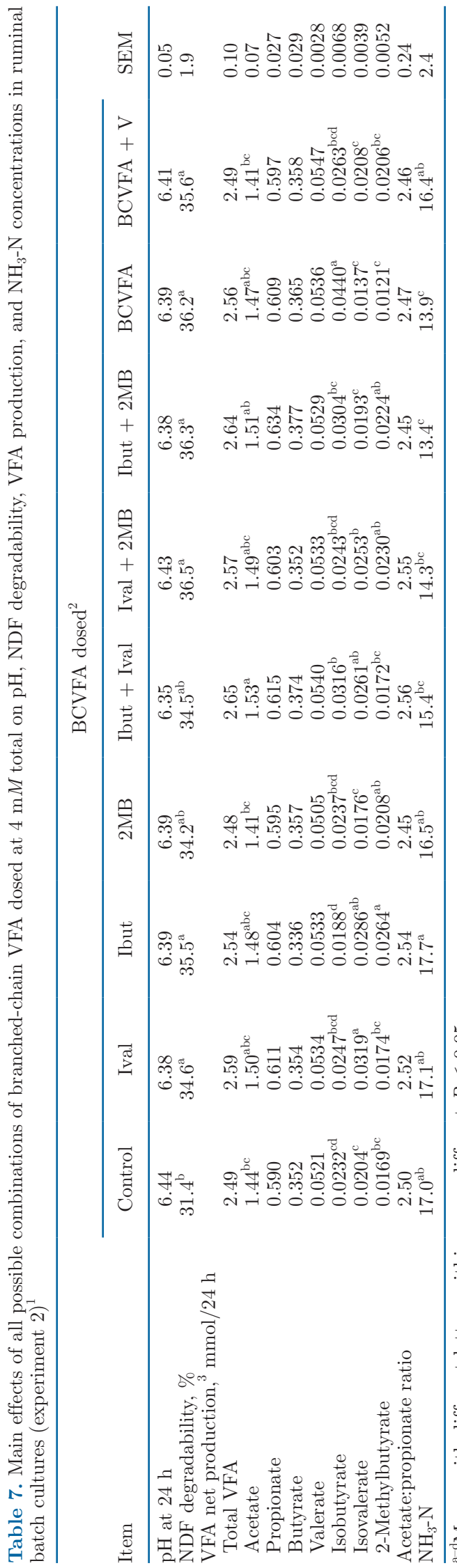

Acetate net production was increased $(P<0.05)$ by Ibut + Ival when compared with either the control, $2 \mathrm{MB}$ alone, or BCVFA + V. Propionate, butyrate, or valerate net production were not affected by BCVFA dosing. Our results are in accordance with most of the studies that have shown no special requirement of valerate by rumen bacteria (Russell and Sniffen, 1984). Isobutyrate net production decreased $(P<0.05)$ when Ibut was added alone compared with when it was added with $2 \mathrm{MB}$ or Ival. In contrast, isobutyrate net production increased $(P<0.05)$ when all the BCVFA were dosed compared with all the other treatments. Russell and Sniffen (1984) did not detect increased bacterial protein synthesis in vitro when adding isobutyrate alone with timothy hay as the substrate. On the other hand, isovalerate net production was the highest when Ival alone was dosed in the current study. Adding Ival alone, Ibut alone, or Ibut + Ival increased $(P \leq 0.05)$ the net production of isovalerate more than did the other combinations of acids and control. Net production of 2-methylbutyrate was increased $(P \leq 0.05)$ by dosing Ibut when compared with either the control, Ival alone, Ibut + Ival, BCVFA, or BCVFA + V. Providing all the BCVFA gave the lowest net production of 2 -methylbutyrate. When $2 \mathrm{MB}$ was given alone or with Ival or Ibut, the net production of 2-methylbutyrate was similar to that when dosing just Ibut. An increase in net production in one BCVFA when other BCVFA were dosed suggests a concentration-dependent competition for BCVFA precursors, whereas a net decrease of one BCVFA when another is dosed would suggest some compensatory mechanism to maintain balance among the individual BCVFA precursors.

Acetate:propionate ratio was not affected by dosing BCVFA (Table 7). Dosing Ibut alone increased $(P \leq$ $0.05) \mathrm{NH}_{3}-\mathrm{N}$ concentration at $24 \mathrm{~h}$ compared with either Ibut + Ival, Ival $+2 \mathrm{MB}$, Ibut $+2 \mathrm{MB}$, and dosing all the BCVFA. Dosing Ibut $+2 \mathrm{MB}$ or all the BCVFA lowered $(P \leq 0.05) \mathrm{NH}_{3}-\mathrm{N}$ concentration compared with all other combinations except compared with Ibut + Ival and Ival $+2 \mathrm{MB}$. All the BCVFA increased $(P$ $<0.05) \mathrm{NDF}$ degradability, and lower $\mathrm{NH}_{3} \mathrm{~N}$ could indicate greater assimilation into microbial protein resulting from that extra degraded substrate. Gorosito et al. (1985) noted lower ammonia concentration in vitro when supplementing each BCVFA individually or BCVFA $+\mathrm{V}$, but there was no change in ammonia when supplementing just valerate. Those authors noted no response for in vitro degradability of wheat straw when supplementing valerate. Valerate can be produced from condensation of acetyl coA with propionate (Weimer and Moen, 2013), probably explaining why acetate partially spared the valerate requirement of $F$. succinogenes (Dehority et al., 1967). 


\section{Experiment 3}

There was a substrate $\times$ BCVFA dosage interaction $(P<0.05)$ for all variables measured in experiment 3 ; therefore, data are presented by substrate. When alfalfa hay + corn was the substrate, adding individual BCVFA did not affect $\mathrm{pH}$ or improve NDF degradtotal VFA, acetate, propionate, butyrate, valerate, or isovalerate were not affected by treatment. Dosing Ival $+2 \mathrm{MB}$ increased $(P \leq 0.05)$ isobutyrate net production compared with dosing control, Ibut, Ibut $+2 \mathrm{MB}$, or all the BCVFA without valerate. Adding $2 \mathrm{MB}$ by itself decreased $(P \leq 0.05)$ 2-methylbutyrate net production compared with adding Ival, Ibut, or Ibut + Ival. With the high concentration of Leu in both alfalfa and ground corn, the resulting increase in isovalerate might need to be countered by adding 2-methylbutyrate. There was no effect of BCVFA dosing on acetate: propionate or $\mathrm{NH}_{3}-\mathrm{N}$ concentration.

Compared with alfalfa, response to BCVFA was better when orchardgrass hay was the forage, probably because of its lower RDP (Table 9). Dosing BCVFA did not affect $\mathrm{pH}$ when grass hay + corn was the substrate. Net production of total VFA, acetate, valerate, and isovalerate was not affected by BCVFA dosing. Adding $2 \mathrm{MB}$ alone, Ibut + Ival, Ibut $+2 \mathrm{MB}$, or BCVFA $+\mathrm{V}$ increased $(P \leq 0.05)$ NDF degradability. Mir et al. (1986) also noted increased in vitro degradability of barley straw with supplementation of any combination of BCVFA. Similar to our study, there was no response to supplementation when alfalfa hay was the substrate. With alfalfa hay as substrate, Ibut $+2 \mathrm{MB}$ improved degradability only when they added them along with pepsin. Those authors argued that higher RDP of alfalfa provided enough BCVFA precursors in the control treatment. Cummins and Papas (1985) also did not observe a response on degradability of alfalfa $(16 \% \mathrm{CP})$ in vitro when supplemented BCVFA. However, when cottonseed meal and corn gluten meal were the substrate, BCVFA increased NDF degradability at similar levels of CP, suggesting the source of protein (i.e., degradability) rather than quantity drives the response. On the other hand, Gorosito et al. (1985) noted BCVFA supplementation increased degradability of alfalfa hay cell wall in vitro, but the increase was greater for orchardgrass ( $4.6 \%$ vs. $7.8 \%$ increase). When only dosing $1 \mathrm{~m} M$ concentrations of each acid (instead of 4 $\mathrm{m} M$ total in experiment 2 ), adding 2 or more acids did not improve degradability compared with adding either Ival or $2 \mathrm{MB}$ alone, even though more acid was available to bacteria when adding 2 or more acids.

Dosing Ibut $+2 \mathrm{MB}$ increased $(P \leq 0.05)$ propionate and butyrate net production compared with dosing Ibut ability at $24 \mathrm{~h}(P>0.10$; Table 8$)$. Net production of

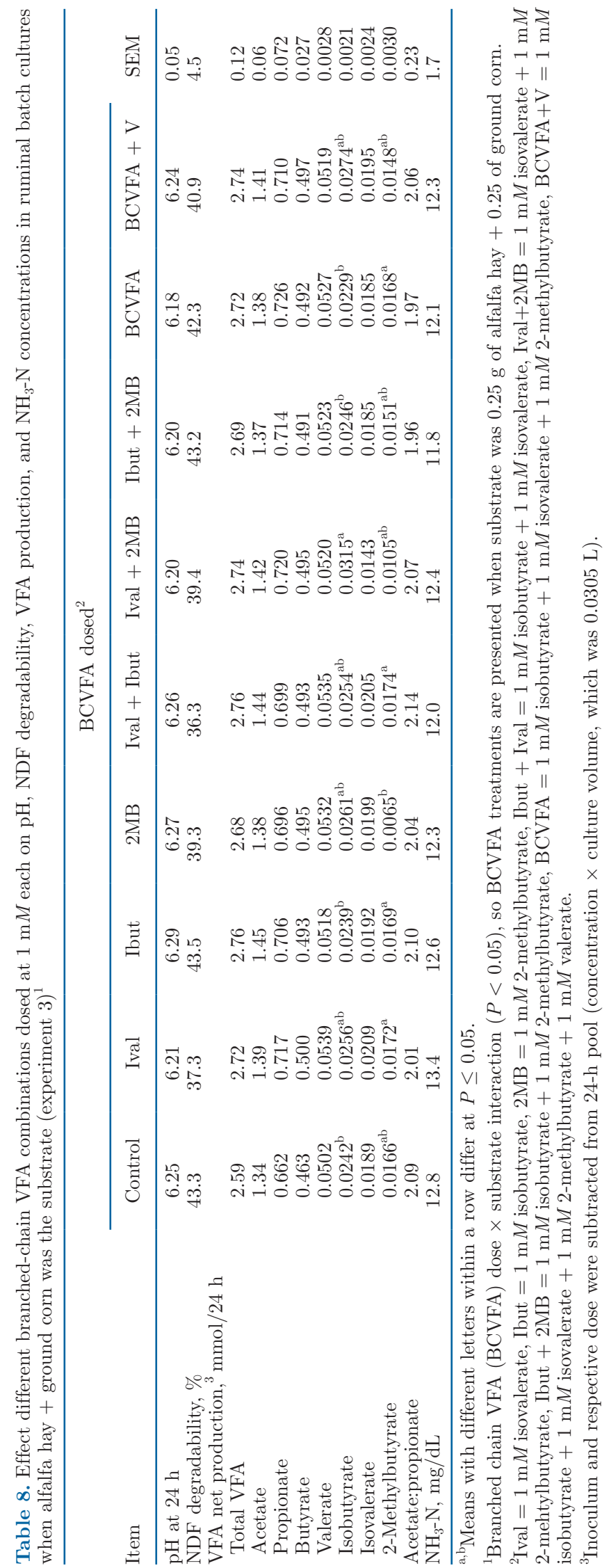

Journal of Dairy Science Vol. 104 No. 6, 2021 


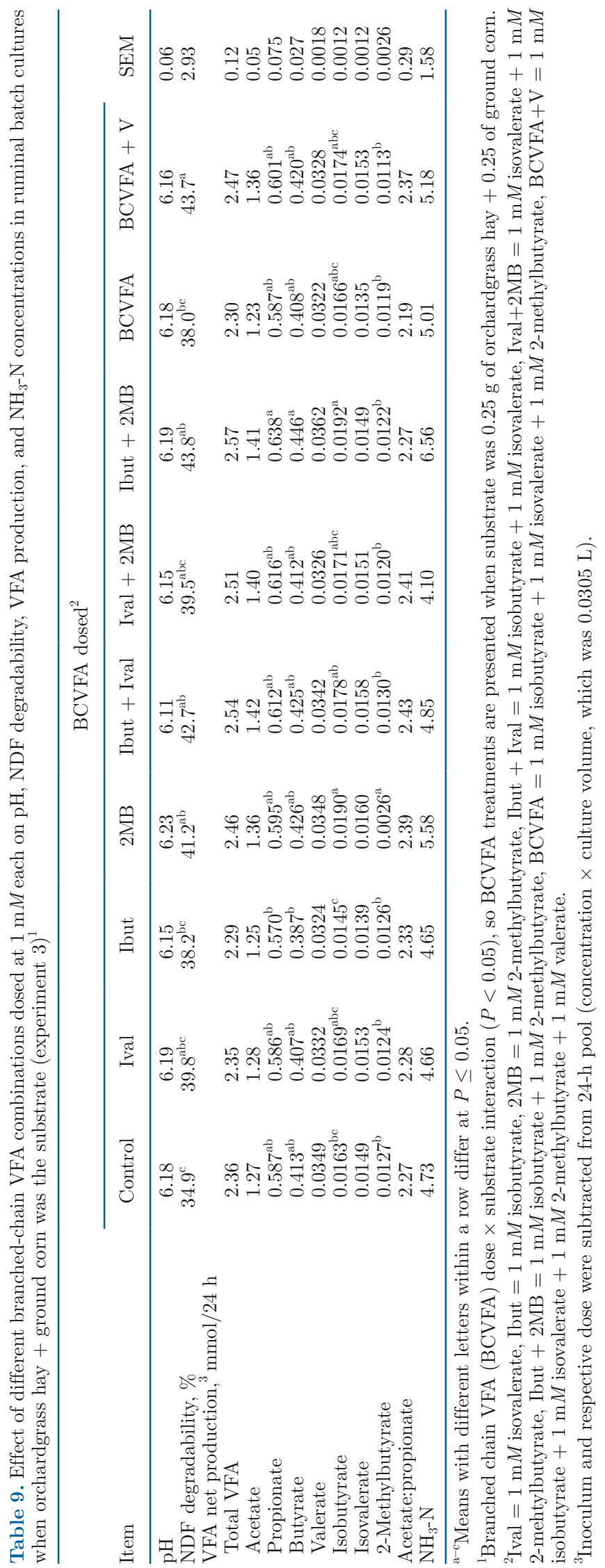

(Table 9). Dosing $2 \mathrm{MB}$ alone or Ibut $+2 \mathrm{MB}$ increased $(P \leq 0.05)$ isobutyrate net production compared with control or when compared with Ibut alone. Adding $2 \mathrm{MB}$ decreased $(P \leq 0.05)$ net production of 2-methylbutyrate compared with all the other combinations and control. As before, isobutyrate seemed to be used more when it was added alone, but 2-methylbutyrate seemed to be preferred over isobutyrate when $2 \mathrm{MB}$ was added. Acetate:propionate and $\mathrm{NH}_{3}-\mathrm{N}$ concentration were not affected by BCVFA dosing when orchardgrass hay + corn was the substrate.

When grass hay and corn was the substrate when compared with alfalfa hay and corn, there was a better response to adding $1 \mathrm{~m} M$ concentrations of acids but only to specific combinations. Dosing $2 \mathrm{MB}$ alone or in combination with Ibut improved NDF degradability and VFA net production. Dosing all the BCVFA $+\mathrm{V}$ increased NDF degradability, but there was no effect on VFA net production and no effect of any of the BCVFA doses on valerate production, again supporting our assertion that valerate does not need supplementation.

To determine which combinations of acids performed the best across all substrate and doses, we ranked each combination for each individual run and substrate (n $=18$; using experiments 2 and 3 ) with the numerically highest NDF degradation being rank 1 to the numerically lowest NDF degradation being rank 9. Mean ranks in order were: Ibut $+2 \mathrm{MB}, \mathrm{BCVFA}$, Ival $+2 \mathrm{MB}$, BCVFA + V, Ibut, Ival, Ival + Ibut, $2 \mathrm{MB}$, and control ranked as $4.25,4.31,4.31,4.44,4.56,5.44,5.50,5.75$, and 6.44, respectively (data not shown).

\section{CONCLUSIONS}

Our batch culture results strongly suggest that BCVFA (but not valerate) have a potential to increase bacterial fibrolytic activity. Production and concentration results suggest BCVFA were extensively produced from BCAA. An increase in FA percentage in bacteria and proportion of the ${ }^{13} \mathrm{C}$ label in $\mathrm{FA}$ from respective labeled BCVFA primers indicates facilitated FA incorporation compared with BCAA. Providing BCAA increased recovery of ${ }^{13} \mathrm{C}$ from labeled $\mathrm{BCAA}$ in the bacteria pellet but not in the FA portion. Higher recoveries of ${ }^{13} \mathrm{C}$ in OBCFA when the ${ }^{13} \mathrm{C}$ label was from BCVFA versus BCAA suggests that a higher intracellular concentration of BCVFA coincided with greatest substrate availability for cellular growth in our batch cultures. The responses observed were more prominent when grass hay + corn was the substrate, probably because of lower RDP in grass hay than alfalfa hay. Adding valerate was not beneficial to increase NDF degradability over just adding the 3 BCVFA. The number of individually supplemented BCVFA could be decreased 
to as few as just 1 acid, but a higher dose of that acid would be needed. Using ranks and accounting for all the combination data, Ibut $+2 \mathrm{MB}$, all $3 \mathrm{BCVFA}$, or Ival + $2 \mathrm{MB}$ were the treatments that had consistently higher NDF degradability, suggesting that Ibut and Ival can substitute for each other, and either or both should be balanced with $2 \mathrm{MB}$ as successful supplements to diets with low preformed AA in RDP, but supplemented with urea to maintain ruminal $\mathrm{NH}_{3}-\mathrm{N}$.

\section{ACKNOWLEDGMENTS}

Research was jointly supported by state and federal funds appropriated to the Ohio Agricultural Research and Development Center, The Ohio State University (OSU; Columbus, OH). Research funds were provided by Zinpro Corporation, Eden Prairie, Minnesota. The Summer Research Opportunity Program at OSU provided funding for 2 years. It is the intent of Zinpro Corporation to eventually commercialize an isoacid product. One of the authors of this paper, M. T. Socha, is an employee of Zinpro Corporation. The authors have not stated any other conflicts of interest.

\section{REFERENCES}

Allison, M. J. 1978. Production of branched-chain volatile fatty acids by certain anaerobic bacteria. Appl. Environ. Microbiol. 35:872877. https://doi.org/10.1128/AEM.35.5.872-877.1978.

Allison, M. J., A. L. Baetz, and J. Wiegel. 1984. Alternative pathways for biosynthesis of leucine and other amino acids in Bacteroides ruminicola and Bacteroides fragilis. Appl. Environ. Microbiol. 48:1111-1117. https://doi.org/10.1128/AEM.48.6.1111-1117.1984.

Allison, M. J., M. P. Bryant, I. Katz, and M. Keeney. 1962. Metabolic function of branched-chain volatile fatty acids, growth factors for ruminococci II: Biosynthesis of higher branched-chain fatty acids and aldehydes. J. Bacteriol. 83:1084-1093. https://doi.org/10 .1128/JB.83.5.1084-1093.1962.

Allison, M. J., and J. L. Peel. 1971. The biosynthesis of valine from isobutyrate by Peptostreptococcus elsdenii and Bacteroides ruminicola. Biochem. J. 121:431-437. https://doi.org/10.1042/bj1210431.

Alves, S. P., J. Santos-Silva, A. R. J. Cabrita, A. J. M. Fonseca, and R. J. B. Bessa. 2013. Detailed dimethylacetal and fatty acid composition of rumen content from lambs fed lucerne or concentrate supplemented with soybean oil. PLoS One 8:e58386. https://doi .org/10.1371/journal.pone.0058386.

Andries, J. I., F. X. Buysse, D. L. De Brabander, and B. G. Cottyn. 1987. Isoacids in ruminant nutrition: Their role in ruminal and intermediary metabolism and possible influences on performances — a review. Anim. Feed Sci. Technol. 18:169-180. https://doi.org/ 10.1016/0377-8401(87)90069-1.

Ankom Technologies. 2017. Neutral detergent fiber in feeds-Filter bag technique (for a2000 and a2000i). Ankom.

Atasoglu, C., A. Y. Guliye, and R. J. Wallace. 2004. Use of stable isotopes to measure de novo synthesis and turnover of amino acid-c and $-\mathrm{n}$ in mixed micro-organisms from the sheep rumen in vitro. Br. J. Nutr. 91:253-262. https://doi.org/10.1079/BJN20031040.

Bach, A., S. Calsamiglia, and M. D. Stern. 2005. Nitrogen metabolism in the rumen. J. Dairy Sci. 88:E9-21. https://doi.org/10.3168/jds .S0022-0302(05)73133-7.

Bremner, J. M., and C. S. Mulvaney. 1982. Nitrogen-total. in Methods of soil analysis, part 1. Chemical and microbiological properties. Vol. Agronomy Monograph no. 9. ASA-SSSA, Madison, WI.
Carmer, S. G., and M. R. Swanson. 1973. An evaluation of ten pairwise multiple comparison procedures by Monte Carlo methods. J. Am. Stat. Assoc. 68:66-74. https://doi.org/10.1080/01621459 .1973 .10481335 .

Chaney, A. L., and E. P. Marbach. 1962. Modified reagents for determination of urea and ammonia. Clin. Chem. 8:130-132. https:// doi.org/10.1093/clinchem/8.2.130.

Cummins, K. A., and A. H. Papas. 1985. Effect of isocarbon-4 and isocarbon-5 volatile fatty acids on microbial protein synthesis and dry matter digestibility in vitro. J. Dairy Sci. 68:2588-2595. https: //doi.org/10.3168/jds.S0022-0302(85)81141-3.

Dehority, B. A., H. W. Scott, and P. Kowaluk. 1967. Volatile fatty acid requirements of cellulolytic rumen bacteria. J. Bacteriol. 94:537543. https://doi.org/10.1128/JB.94.3.537-543.1967.

Eibler, D., H. Abdurahman, T. Ruoff, S. Kaffarnik, H. Steingass, and W. Vetter. 2017. Unexpected formation of low amounts of (r)configurated anteiso-fatty acids in rumen fluid experiments. PLoS One 12:e0170788. https://doi.org/10.1371/journal.pone.0170788.

Firkins, J. L. 2010. Reconsidering rumen microbial consortia to enhance feed efficiency and reduce environmental impact of ruminant livestock production systems. Rev. Bras. Zootec. 39(suppl spe):445-457. https://doi.org/10.1590/S1516-35982010001300049.

Geiger, O., N. González-Silva, I. M. López-Lara, and C. Sohlenkamp. 2010. Amino acid-containing membrane lipids in bacteria. Prog. Lipid Res. 49:46-60. https://doi.org/10.1016/j.plipres.2009.08.002.

Goering, H. K., and P. J. Van Soest. 1970. Forage fiber analyses (apparatus, reagents, procedures, and some applications). Pages 1-20 in Agric. Handbook. Vol. no. 379. ARS-USDA, ed. USDA Agricultural Research Service.

Goldfine, H. 2017. The anaerobic biosynthesis of plasmalogens. FEBS Lett. 591:2714-2719. https://doi.org/10.1002/1873-3468.12714.

Gorosito, A. R., J. B. Russell, and P. J. Van Soest. 1985. Effect of carbon- 4 and carbon- 5 volatile fatty acids on digestion of plant cell wall in vitro. J. Dairy Sci. 68:840-847. https://doi.org/10.3168/jds .S0022-0302(85)80901-2.

Gruninger, R. J., G. O. Ribeiro, A. Cameron, and T. A. McAllister. 2019. Invited review: Application of meta-omics to understand the dynamic nature of the rumen microbiome and how it responds to diet in ruminants. Animal 13:1843-1854. https://doi.org/10.1017/ S1751731119000752.

Hackmann, T. J., and J. L. Firkins. 2015. Electron transport phosphorylation in rumen butyrivibrios: Unprecedented ATP yield for glucose fermentation to butyrate. Front. Microbiol. 6:622. https:// doi.org/10.3389/fmicb.2015.00622.

Hino, T., and J. B. Russell. 1985. Effect of reducing-equivalent disposal and $\mathrm{NADH} / \mathrm{NAD}$ on deamination of amino acids by intact rumen microorganisms and their cell extracts. Appl. Environ. Microbiol. 50:1368-1374. https://doi.org/10.1128/AEM.50.6.1368-1374.1985.

Hristov, A. N., P. Huhtanen, L. M. Rode, S. N. Acharya, and T. A. McAllister. 2001. Comparison of the ruminal metabolism of nitrogen from ${ }^{15} \mathrm{~N}$-labeled alfalfa preserved as hay or as silage. J. Dairy Sci. 84:2738-2750. https://doi.org/10.3168/jds.S0022 $-0302(01) 74728-5$.

Kaiser, J. C., and D. E. Heinrichs. 2018. Branching out: Alterations in bacterial physiology and virulence due to branched-chain amino acid deprivation. MBio 9:e01188-18. https://doi.org/10.1128/ mBio.01188-18.

Kajikawa, H., M. Mitsumori, and S. Ohmomo. 2002. Stimulatory and inhibitory effects of protein amino acids on growth rate and efficiency of mixed ruminal bacteria. J. Dairy Sci. 85:2015-2022. https://doi.org/10.3168/jds.S0022-0302(02)74278-1.

Kaneda, T. 1977. Fatty acids of the genus Bacillus: An example of branched-chain preference. Bacteriol. Rev. 41:391-418. https://doi .org/10.1128/BR.41.2.391-418.1977.

Kaneda, T. 1991. Iso- and anteiso-fatty acids in bacteria: Biosynthesis, function, and taxonomic significance. Microbiol. Rev. 55:288-302. https://doi.org/10.1128/MR.55.2.288-302.1991.

Minato, H., S. Ishibashi, and T. Hamaoka. 1988. Cellular fatty acid and sugar composition of representative strain of rumen bacteria. J. Gen. Appl. Microbiol. 34:303-319. https://doi.org/10.2323/ jgam.34.303. 
Mir, P. S., Z. Mir, and J. A. Robertson. 1986. Effect of branched-chain amino acids or fatty acid supplementation on in vitro digestibility of barley straw or alfalfa hay. Can. J. Anim. Sci. 66:151-156. https: //doi.org/10.4141/cjas86-016.

Misra, A. K., and S. S. Thakur. 2012. Effect of sodium salts of branched chain volatile fatty acids on extra cellular ammonia utilization and protein production in vitro. Indian J. Anim. Sci. 82:400-404.

Moon, M., and K. L. Anderson. 2001. Eubacterium cellulosolvens alters its membrane protein, lipoprotein, and fatty acid composition in response to growth on cellulose. Anaerobe 7:227-236. https://doi .org/10.1006/anae.2001.0389.

Moraïs, S., and I. Mizrahi. 2019. Islands in the stream: From individual to communal fiber degradation in the rumen ecosystem. FEMS Microbiol. Rev. 43:362-379. https://doi.org/10.1093/ femsre/fuz007.

Parsons, J. B., and C. O. Rock. 2013. Bacterial lipids: Metabolism and membrane homeostasis. Prog. Lipid Res. 52:249-276. https://doi org/10.1016/j.plipres.2013.02.002.

Robinson, I. M., and M. J. Allison. 1969. Isoleucine biosynthesis from 2-methylbutyric acid by anaerobic bacteria from the rumen. J. Bacteriol. 97:1220-1226. https://doi.org/10.1128/JB.97.3.1220 $-1226.1969$.

Roman-Garcia, Y., R. R. White, and J. L. Firkins. 2016. Meta-analysis of postruminal microbial nitrogen flows in dairy cattle. I. Derivation of equations. J. Dairy Sci. 99:7918-7931. https://doi.org/10 $.3168 /$ jds.2015-10661.

Russell, J. B., and C. J. Sniffen. 1984. Effect of carbon-4 and carbon-5 volatile fatty acids on growth of mixed rumen bacteria in vitro. J. Dairy Sci. 67:987-994. https://doi.org/10.3168/jds.S0022 $-0302(84) 81397-1$.

Sasser, M. 1990. MIDI technical note 101. Pages 1-7 in Identification of Bacteria by Gas Chromatography of Cellular Fatty Acids. MIDI.

Sok, M., D. R. Ouellet, J. L. Firkins, D. Pellerin, and H. Lapierre. 2017. Amino acid composition of rumen bacteria and protozoa in cattle. J. Dairy Sci. 100:5241-5249. https://doi.org/10.3168/ jds.2016-12447.

Stewart, C. S., H. J. Flint, and M. P. Bryant. 1997. The rumen bacteria. Pages 10-72 in The Rumen Microbial Ecosystem. 2nd ed. C. S. Stewart and P. N. Hobson, ed. Chapman and Hall.

Suen, G., P. J. Weimer, D. M. Stevenson, F. O. Aylward, J. Boyum, J. Deneke, C. Drinkwater, N. N. Ivanova, N. Mikhailova, O. Chertkov, L. A. Goodwin, C. R. Currie, D. Mead, and P. J. Brumm. 2011. The complete genome sequence of Fibrobacter succinogenes S85 reveals a cellulolytic and metabolic specialist. PLoS One 6:e18814. https://doi.org/10.1371/journal.pone.0018814.

Terry, S. A., A. Badhan, Y. Wang, A. V. Chaves, and T. A. McAllister. 2019. Fibre digestion by rumen microbiota - A review of recent metagenomic and metatranscriptomic studies. Can. J. Anim. Sci. 99:678-692. https://doi.org/10.1139/cjas-2019-0024.

Van Soest, P. J., J. B. Robertson, and B. A. Lewis. 1991. Methods for dietary fiber, neutral detergent fiber, and nonstarch polysaccharides in relation to animal nutrition. J. Dairy Sci. 74:3583-3597. https://doi.org/10.3168/jds.S0022-0302(91)78551-2.

Vlaeminck, B., V. Fievez, A. R. J. Cabrita, A. J. M. Fonseca, and R. J. Dewhurst. 2006a. Factors affecting odd- and branched-chain fatty acids in milk: A review. Anim. Feed Sci. Technol. 131:389-417. https://doi.org/10.1016/j.anifeedsci.2006.06.017.
Vlaeminck, B., V. Fievez, D. Demeyer, and R. J. Dewhurst. 2006b. Effect of forage:concentrate ratio on fatty acid composition of rumen bacteria isolated from ruminal and duodenal digesta. J. Dairy Sci. 89:2668-2678. https://doi.org/10.3168/jds.S0022-0302(06)72343 -8 .

Wang, C., Q. Liu, G. Guo, W. J. Huo, C. X. Pei, S. L. Zhang, and H. Wang. 2018. Effects of concentrate-to-forage ratios and 2-methylbutyrate supplementation on ruminal fermentation, bacteria abundance and urinary excretion of purine derivatives in Chinese Simmental steers. J. Anim. Physiol. Anim. Nutr. (Berl.). https:// doi.org/10.1111/jpn.12915.

Ward, D. E., C. C. van der Weijden, M. J. van der Merwe, H. V. Westerhoff, A. Claiborne, and J. L. Snoep. 2000. Branched-chain $\alpha$-keto acid catabolism via the gene products of the $b k d$ operon in Enterococcus faecalis: A new, secreted metabolite serving as a temporary redox sink. J. Bacteriol. 182:3239-3246. https://doi.org/10 .1128/JB.182.11.3239-3246.2000.

Wegner, G. H., and E. M. Foster. 1963. Incorporation of isobutyrate and valerate into cellular plasmalogen by Bacteroides succinogenes. J. Bacteriol. 85:53-61. https://doi.org/10.1128/JB.85.1 $.53-61.1963$

Weimer, P. J., and G. N. Moen. 2013. Quantitative analysis of growth and volatile fatty acid production by the anaerobic ruminal bacterium Megasphaera elsdenii t81. Appl. Microbiol. Biotechnol. 97:4075-4081. https://doi.org/10.1007/s00253-012-4645-4.

Wenner, B. A., B. K. Wagner, N. R. St-Pierre, Z. T. Yu, and J. L. Firkins. 2020. Inhibition of methanogenesis by nitrate, with or without defaunation, in continuous culture. J. Dairy Sci. 103:71247140. https://doi.org/10.3168/jds.2020-18325.

Whitehouse, N. L., V. M. Olson, C. G. Schwab, W. R. Chesbro, K. D. Cunningham, and T. Lykos. 1994. Improved techniques for dissociating particle-associated mixed ruminal microorganisms from ruminal digesta solids. J. Anim. Sci. 72:1335-43.

Wu, Z., and D. L. Palmquist. 1991. Synthesis and biohydrogenation of fatty acids by ruminal microorganisms in vitro. J. Dairy Sci 74:3035-3046. https://doi.org/10.3168/jds.S0022-0302(91)78489 -0 .

Yang, W. Z., K. A. Beauchemin, and L. M. Rode. 2002. Effects of particle size of alfalfa-based dairy cow diets on site and extent of digestion. J. Dairy Sci. 85:1958-1968. https://doi.org/10.3168/jds .S0022-0302(02)74272-0.

Zhang, H. L., Y. Chen, X. L. Xu, and Y. X. Yang. 2013. Effects of branched-chain amino acids on in vitro ruminal fermentation of wheat straw. Asian-Australas. J. Anim. Sci. 26:523-528. https:// doi.org/10.5713/ajas.2012.12539.

\section{ORCIDS}

Y. Roman-Garcia @ https://orcid.org/0000-0001-8181-2470

B. L. Denton () https://orcid.org/0000-0002-2969-2915

K. E. Mitchell ( https://orcid.org/0000-0002-9769-3960

C. Lee (ํ) https://orcid.org/0000-0002-4522-1232

M. T. Socha () https://orcid.org/0000-0002-0227-6591

J. L. Firkins @ https://orcid.org/0000-0003-3518-1940 